\title{
Biotic stress accelerates formation of climate-relevant aerosols in boreal forests
}

\author{
J. Joutsensaari ${ }^{1}$, P. Yli-Pirilä ${ }^{1,2}$, H. Korhonen ${ }^{1,6}$, A. Arola ${ }^{3}$, J. D. Blande ${ }^{2}$, J. Heijari ${ }^{4}$, M. Kivimäenpää ${ }^{2}$, \\ S. Mikkonen ${ }^{1}$, L. Hao ${ }^{1}$, P. Miettinen ${ }^{1}$, P. Lyytikäinen-Saarenmaa ${ }^{5}$, C. L. Faiola ${ }^{1}$, A. Laaksonen ${ }^{1,6}$, and \\ J. K. Holopainen ${ }^{2}$ \\ ${ }^{1}$ Department of Applied Physics, University of Eastern Finland, P.O. Box 1627, 70211 Kuopio, Finland \\ ${ }^{2}$ Department of Environmental Science, University of Eastern Finland, P.O. Box 1627, 70211 Kuopio, Finland \\ ${ }^{3}$ Finnish Meteorological Institute, Atmospheric Research Centre of Eastern Finland, P.O. Box 1627, 70211 Kuopio, Finland \\ ${ }^{4}$ Neste Oil Oyj, P.O. Box 95, 00095 NESTE OIL, Finland \\ ${ }^{5}$ Department of Forest Sciences, University of Helsinki, P.O. Box 27, 00014 University of Helsinki, Finland \\ ${ }^{6}$ Finnish Meteorological Institute, P.O. Box 503, 00101 Helsinki, Finland
}

Correspondence to: J. Joutsensaari (jorma.joutsensaari@uef.fi)

Received: 23 March 2015 - Published in Atmos. Chem. Phys. Discuss.: 14 April 2015

Revised: 3 July 2015 - Accepted: 21 October 2015 - Published: 2 November 2015

\begin{abstract}
Boreal forests are a major source of climaterelevant biogenic secondary organic aerosols (SOAs) and will be greatly influenced by increasing temperature. Global warming is predicted to not only increase emissions of reactive biogenic volatile organic compounds (BVOCs) from vegetation directly but also induce large-scale insect outbreaks, which significantly increase emissions of reactive BVOCs. Thus, climate change factors could substantially accelerate the formation of biogenic SOAs in the troposphere. In this study, we have combined results from field and laboratory experiments, satellite observations and global-scale modelling in order to evaluate the effects of insect herbivory and large-scale outbreaks on SOA formation and the Earth's climate. Field measurements demonstrated 11fold and 20-fold increases in monoterpene and sesquiterpene emissions respectively from damaged trees during a pine sawfly (Neodiprion sertifer) outbreak in eastern Finland. Laboratory chamber experiments showed that feeding by pine weevils (Hylobius abietis) increased VOC emissions from Scots pine and Norway spruce seedlings by $10-50$ fold, resulting in 200-1000-fold increases in SOA masses formed via ozonolysis. The influence of insect damage on aerosol concentrations in boreal forests was studied with a global chemical transport model GLOMAP and MODIS satellite observations. Global-scale modelling was performed using a 10-fold increase in monoterpene emission rates and as-
\end{abstract}

suming $10 \%$ of the boreal forest area was experiencing outbreak. Results showed a clear increase in total particulate mass (local max. $480 \%$ ) and cloud condensation nuclei concentrations $(45 \%)$. Satellite observations indicated a 2-fold increase in aerosol optical depth over western Canada's pine forests in August during a bark beetle outbreak. These results suggest that more frequent insect outbreaks in a warming climate could result in substantial increase in biogenic SOA formation in the boreal zone and, thus, affect both aerosol direct and indirect forcing of climate at regional scales. The effect of insect outbreaks on VOC emissions and SOA formation should be considered in future climate predictions.

\section{Introduction}

Atmospheric aerosols have a strong but highly uncertain influence on the Earth's radiation balance and climate (IPCC, 2013). Formation of secondary organic aerosols (SOAs) in the troposphere, i.e. particle production by oxidation of volatile organic compounds (VOCs), is one of the main processes affecting composition and properties of atmospheric aerosols (Hallquist et al., 2009; Jimenez et al., 2009; Kanakidou et al., 2005). VOC emissions from vegetation (i.e. biogenic VOCs) are important precursors for SOAs (Claeys et al., 2004; Kanakidou et al., 2005; Kavouras et al., 1998; 
Guenther et al., 1995) as first suggested in 1960 (blue haze; Went, 1960). On a global scale, biogenic VOC emissions to the atmosphere, mainly monoterpenes and isoprene from terrestrial ecosystems, constitute about $90 \%$ of all global VOC emissions (Guenther et al., 1995) and therefore have an important impact on the global climate. Plant-emitted VOCs readily react with atmospheric oxidants, forming lowvolatility oxidation products that may have a key role in new particle formation in forested areas (Ehn et al., 2014; Kulmala et al., 2013; Laaksonen et al., 2008). The boreal zone is estimated to be a major source of climate-relevant biogenic aerosol particles (Tunved et al., 2006a) and, in a warmer climate, boreal forests may emit sufficiently large amounts of organic vapours to modify cloud albedo and cool the climate (Spracklen et al., 2008b). However, the contribution of biogenic VOCs to the global aerosol burden is still unclear.

Boreal coniferous and mixed deciduous forests cover a land area of about 21.5 million $\mathrm{km}^{2}$ at northern latitudes (Potapov et al., 2008) and they will be greatly influenced by increasing temperature (IPCC, 2013; Mikkonen et al., 2014). The huge boreal forest biome has the potential to substantially affect global temperatures by controlling the atmospheric $\mathrm{CO}_{2}$ concentration (Kurz et al., 2008a) and land surface albedo (Bala et al., 2007). However, conifers are known to be sensitive to pest and disease outbreaks (Kurz et al., 2008a, b). Global warming is predicted to induce large-scale insect outbreaks in the boreal forests (Kurz et al., 2008a; Niemelä et al., 2001; Veteli et al., 2005). Herbivorous insect species could survive better in a warming climate by moving to higher latitudes and escaping from their natural enemies (Berryman, 1987). High mortality of over-wintering herbivorous insect stages due to low winter temperatures is crucial to limiting population growth (Kurz et al., 2008a; Veteli et al., 2005) and therefore climate warming will facilitate large-scale insect outbreaks (Niemelä et al., 2001). In recent years, about $130000 \mathrm{~km}^{2}$ of Canada's pine forests have been affected by large-scale mountain pine beetle outbreaks, and only extremely cold weather is expected to stop the epidemic (Kurz et al., 2008a). The dominating outbreak species in Eurasian forests will be pine sawflies on Scots pine (De Somviele et al., 2007), autumnal moth on mountain birch and winter moth on deciduous tree species (Niemelä et al., 2001).

Feeding by insects induces larger and more diverse biogenic VOC emissions from plants (Blande et al., 2007; Holopainen and Gershenzon, 2010). Herbivore damage to deciduous (Blande et al., 2007) and coniferous (Blande et al., 2009; Amin et al., 2012; Berg et al., 2013; Ghimire et al., 2013) boreal trees results in a substantial increase in highly reactive VOC emissions, e.g. sesquiterpenes (Bonn and Moortgat, 2003). Our first plant chamber experiments (Joutsensaari et al., 2005) demonstrated that simulation of herbivore feeding by a chemical elicitor substantially increased new particle formation by ozonolysis. Furthermore, recent chamber and modelling studies have shown that insect infestation can significantly increase SOA formation (Mentel et al., 2013; Berg et al., 2013; Bergström et al., 2014).

To understand climate change effects on SOA formation in herbivore-stressed forests, there is an urgent need for an integrated interdisciplinary approach that evaluates plant biological, ecological and atmospheric processes concomitantly. In this study, we combined results from field and laboratory experiments, satellite observations and global-scale modelling in order to evaluate the effects of insect herbivory and largescale outbreaks on SOA formation and the Earth's climate. Here we show that insect feeding increases the total VOC emission rates from coniferous trees (i.e. Scots pine and Norway spruce) and significantly enhances formation of climaterelevant aerosols. Firstly, the effects of insect feeding on tree VOC emissions in the boreal forest site and in laboratory experiments were assessed. Secondly, SOA formation by oxidation of plant-emitted VOCs was studied in the laboratory using current ambient $(50 \mathrm{ppb})$ and potential future peak $(200 \mathrm{ppb})$ tropospheric ozone levels. Finally, the influence of large-scale insect outbreaks on local aerosol and cloud condensation nuclei (CCN) concentrations were investigated using satellite observations and global-scale modelling.

\section{Materials and methods}

\subsection{Field experiments}

To assess the effects of an insect outbreak on VOC emission rates of a forest stand, a field study was conducted at the site of a European pine sawfly, Neodiprion sertifer (Geoffroy; Hymenoptera: Diprionidae), outbreak in Outokumpu, eastern Finland $\left(62^{\circ} 47^{\prime} 02^{\prime \prime} \mathrm{N}, 2^{\circ} 01^{\prime} 32^{\prime \prime} \mathrm{E}\right)$, on 30 June 2010. The outbreak covered an area of 50000 hectares, reaching a maximal point in 2009 and showing the first signs of retrogradation in 2010. The mean stand characteristics were the following: 14.2 years of age, height of $2.23 \mathrm{~m}$, diameter at breast height $1.99 \mathrm{~cm}$ and needle loss rate of $20 \%$ at the end of the growing season. We measured VOC emissions from intact Scots pine trees and trees damaged by the European pine sawfly during the larval feeding period.

We collected VOCs from one branch (third or fourth whorl from the top of the crown) of 10 non-damaged control trees and 10 sawfly-damaged Scots pine trees (for technical reasons, three samples were lost). Polyethylene terephthalate (PET) bags (size $45 \times 55 \mathrm{~cm}$; LOOK, Terinex Ltd, Bedford, England) were heated at $+120^{\circ} \mathrm{C}$ for $1 \mathrm{~h}$ before collection to remove any contaminants from the bag and subsequently cooled. One lateral branch (including the two youngest needle year classes and feeding larvae on the previous year shoots of damaged seedlings) was enclosed inside the PET bag and fastened securely to the bark taking care not to damage any foliage. The temperature inside the bags was monitored with wireless temperature/humidity loggers (Hygrochron DS1923-F5 iButton, Maxim Integrated Products, 
Inc., CA). One of the two outermost bag corners was cut and an air inlet was inserted and fastened with a shutter. Clean charcoal-filtered and $\mathrm{MnO}_{2}$ scrubbed air was pumped through Teflon tubing and into the bag at $600 \mathrm{~mL} \mathrm{~min}^{-1}$ for $15 \mathrm{~min}$ to flush the system and then reduced to $300 \mathrm{~mL} \mathrm{~min}^{-1}$ during collections. The volume of the bag was ca. $2 \mathrm{~L}$ during the collection. The remaining bag corner was cut and a stainless steel tube containing approximately $150 \mathrm{mg}$ of Tenax TA-adsorbent (Supelco, mesh 60/80) was inserted and fastened into position. Air was pulled through the Tenax tube by battery-operated sampling pumps (Rietschle Thomas, Puchheim, Germany). For the 15 min sampling period the air flow through the Tenax tube was set to $200 \mathrm{~mL} \mathrm{~min}^{-1}$ with an M-5 bubble flowmeter (A.P. Buck, Orlando, FL, USA). A higher flow of the purified replacement air than that into the Tenax tube ensured that no outside VOCs entered the collection bags.

The VOC samples were analysed with a gas chromatograph-mass spectrometer (Hewlett-Packard GC 6890, MSD 5973, Beaconsfield, UK). Trapped compounds were desorbed with a thermal desorption unit (Perkin-Elmer ATD400 Automatic Thermal Desorption system, Wellesley, MA, USA) at $250{ }^{\circ} \mathrm{C}$ for $10 \mathrm{~min}$, cryofocused at $-30{ }^{\circ} \mathrm{C}$ and injected onto an HP-5 capillary column $(50 \mathrm{~m} \times 0.2 \mathrm{~mm}$ i.d. $\times 0.5 \mu \mathrm{m}$ film thickness, Hewlett-Packard) with helium as a carrier gas. The oven temperature program was held at $40^{\circ} \mathrm{C}$ for $1 \mathrm{~min}$ and then raised to $210^{\circ} \mathrm{C}$ at a rate of $5^{\circ} \mathrm{C} \mathrm{min}{ }^{-1}$ and to a final temperature of $250^{\circ} \mathrm{C}$ at a rate of $20^{\circ} \mathrm{C} \mathrm{min}^{-1}$. The compounds (mono-, homo- and sesquiterpenes and green leaf volatiles, GLVs) were identified by comparing their mass spectra with those in the Wiley library and with pure standards. Monoterpene and sesquiterpene emissions were standardised to $30{ }^{\circ} \mathrm{C}$ using previously published algorithms (Guenther et al., 1993; Helmig et al., 2006). Results per unit of needle biomass per hour were calculated as in Faubert et al. (2010) with flow rates into the collection bag and the Tenax tubes taken into account.

\subsection{Laboratory experiments}

\subsubsection{Chamber experiments}

Figure 1 shows a schematic presentation of the set-up of the plant chamber experiments and Table 1 summarises the chamber experiments conducted in this study. The SOA formation experiments were carried out in a continuous flow chamber made of Neoflon ${ }^{\mathrm{TM}}$ FEP film (type NF-0050, Daikin Industries, Ltd, Japan). The reaction chamber volume was $2 \mathrm{~m}^{3}(1.2 \mathrm{~m} \times 1.2 \mathrm{~m} \times 1.4 \mathrm{~m})$ with an aluminium supporting frame. Air flow from the seedling headspace $\left(2 \mathrm{~L} \mathrm{~min}^{-1}\right)$ was mixed with an ozone-enriched air flow (target concentrations $45 \pm 5$ and $190 \pm 10 \mathrm{ppb}$ ) in a T-fitting at the inlet of the reactor. The total air flow into the reaction chamber was $17 \mathrm{~L} \mathrm{~min}^{-1}$ with an average residence time of $2 \mathrm{~h}$. At the beginning of the trials, VOCs from seedlings were intro-

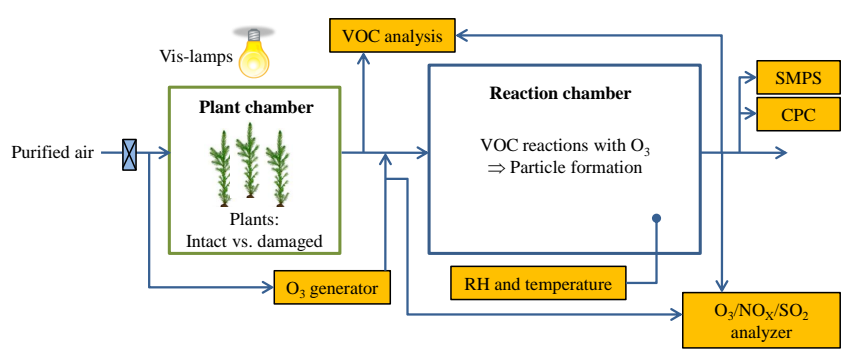

Figure 1. Schematic presentation of the chamber experiment set-up. VOC emissions from tree seedlings were continuously channelled from a plant chamber (left) to a reaction chamber (right). At the inlet of the reaction chamber, the air flow from trees was mixed with an ozone-rich air flow. SMPS denotes a scanning mobility particle sizer and CPC denotes a condensation particle counter.

duced into the chamber $60 \mathrm{~min}$ (pine) or $90 \mathrm{~min}$ (spruce) before ozone addition. The duration of the chamber experiment was ca. $21 \mathrm{~h}$. The plants diurnal cycle was mimicked by turning off the lights over plant chambers from 24:00 to 03:00 $(\mathrm{UTC}+3)$. In all experiments, ozone (measured with a DASIBI 1008-RS $\mathrm{O}_{3}$ analyzer), $\mathrm{NO}_{x}$ (Environnement S.A AC $30 \mathrm{M} \mathrm{NO}_{x}$ analyzer) and $\mathrm{SO}_{2}$ (Environnement S.A AF21M $\mathrm{SO}_{2}$ analyzer) concentrations were monitored at the inlet and outlet of the chamber. $\mathrm{NO}_{x}$ and $\mathrm{SO}_{2}$ values were below detection limits of the analysers $(2 \mathrm{ppb})$ during experiments. Ozone concentrations inside the chamber were stabilised ca. 4-5 $\mathrm{h}$ after the start of addition.

\subsubsection{Plant material and insect treatment}

Scots pine Pinus sylvestris L. seedlings (3 years old) and Norway spruce Picea abies L. Karst. seedlings (3 years old) were used as natural VOC emitters. They were grown in $5 \mathrm{~L}$ plastic pots in a mixture of quartz sand and Sphagnum peat. Two intact or insect-damaged seedlings were selected for each SOA formation experiment. Pot soil was covered with tightly sealed aluminium foil to prevent VOC emission and particle release from the soil entering the plant headspace. Whole plants were enclosed individually in transparent PET bags ( size $45 \times 55 \mathrm{~cm}$; LOOK, Terinex Ltd, Bedford, England), which were cleaned by pre-heating for $1 \mathrm{~h}$ at $120^{\circ} \mathrm{C}$. The opening of the bag was sealed around the outer surface of the polyethylene pot with duct tape. The two outermost corners of the bags were cut, and Teflon tubes were inserted through each. One tube was an air inlet through which clean filtered air was pumped, and the second was an outlet channelling plant headspace air from the bag and into the reaction chamber. Six fluorescent lamps (OSRAM Dulux F 24W/41827, Osram-Melco Ltd., Japan) were positioned around the plants to ensure optimal photosynthesis activity (PAR ca. $350 \mu \mathrm{mmol} \mathrm{m}^{-2} \mathrm{~s}^{-1}$ ) and VOC emissions at laboratory conditions $\left(24^{\circ} \mathrm{C}\right)$. 
Table 1. Summary of conducted chamber experiments: average ozone concentrations at the inlet $\left(\mathrm{O}_{3_{\text {inlet }}}\right)$ and outlet $\left(\mathrm{O}_{3_{\text {outlet }}}\right)$ of the reaction chamber, relative humidity $(\mathrm{RH})$ and temperature during experiments.

\begin{tabular}{lllrrrr}
\hline$\#$ & Date & Experiment & $\mathrm{O}_{3_{\text {inlet }}}$ & $\mathrm{O}_{3_{\text {outlet }}}$ & $\mathrm{RH}$ & $T$ \\
\hline & & & $(\mathrm{ppb})$ & $(\mathrm{ppb})$ & $(\%)$ & $\left({ }^{\circ} \mathrm{C}\right)$ \\
\hline 1 & $9-10.6 .2008$ & Spruce, control & 170 & 145 & 5 & 24 \\
2 & $12-13.6 .2008$ & Spruce, control & 166 & 132 & 9 & 24 \\
3 & $10-11.6 .2008$ & Spruce, damaged & 171 & 140 & 9 & 24 \\
4 & $11-12.6 .2008$ & Spruce, damaged & 164 & 132 & 11 & 24 \\
5 & $15-16.6 .2008$ & Pine, control & 172 & 143 & 9 & 24 \\
\hline 6 & $18-19.6 .2008$ & Pine, control & 164 & 129 & 14 & 25 \\
7 & $16-17.6 .2008$ & Pine, damaged & 175 & 120 & 12 & 24 \\
8 & $17-18.6 .2008$ & Pine, damaged & 164 & 97 & 16 & 25 \\
\hline 9 & $9-10.7 .2008$ & Pine, control & 41 & 29 & 13 & 24 \\
10 & $10-11.7 .2008$ & Pine, control & 39 & 28 & 14 & 24 \\
11 & $7-8.7 .2008$ & Pine, damaged & 37 & 21 & 13 & 24 \\
12 & $8-9.7 .2008$ & Pine, damaged & 41 & 21 & 13 & 24 \\
\hline
\end{tabular}

Each pine and spruce seedling used in chamber experiments had an insect enclosure fitted to the stem. Enclosures were made of polyester mesh and polypropylene foam. Plants damaged by herbivores were infested with four large pine weevil Hylobius abietis L. (Coleoptera: Curculionidae) adults that were added to the enclosures. All weevils were kept without food for $24 \mathrm{~h}$ prior to experiments to promote feeding and were left to feed on the stem bark for $48 \mathrm{~h}$ before the start of the SOA formation experiment. Insect enclosures attached to control seedlings remained empty. When PET bags were installed for SOA experiments, the weevils and enclosures were removed from plants.

\subsubsection{VOC and aerosol measurements}

VOCs were collected in tubes containing about $150 \mathrm{mg}$ of Tenax TA adsorbent (Supelco, mesh 60/80) for $30 \mathrm{~min}$ with an air flow through the sample tube of $200 \mathrm{~mL} \mathrm{~min}^{-1}$. GCMS analysis was the same as in the field experiment but temperature standardisation was not done. VOC emissions were quantified as $\mathrm{ng} \mathrm{g}^{-1}$ (DW) $\mathrm{h}^{-1}$ using needle biomass in calculations as weevils only damage conifer bark, but their feeding induces emissions from intact needles in the distal part of the plant (Blande et al., 2009)

Particle number concentrations were measured with a condensation particle counter (CPC; TSI Model 3775, minimum detectable particle diameter $4 \mathrm{~nm}$ ) and calculated from particle number size distributions. Particle size distributions between 15 and $740 \mathrm{~nm}$ were measured every $3 \mathrm{~min}$ at the outlet of the chamber using a scanning mobility particle sizer (SMPS), consisting of a TSI Model 3071A electrostatic classifier and a TSI Model 3022A CPC. Particle total mass concentration was calculated from measured number size distribution assuming spherical particle shape and using a density of $1.4 \mathrm{~g} \mathrm{~cm}^{-3}$ for SOA particles (Hao et al., 2009).
SOA mass yields were estimated by dividing the formed SOA mass (averaged over several measurements) by the reacted VOC concentrations (i.e. the total terpene concentration at the reactor inlet minus the concentration at the outlet; Shilling et al., 2008). SOA mass yields were only calculated for steady-state situations (i.e. day, night, morning) and thus the first hours of trials with the intensive particle formation were excluded. The experiments were conducted without seed particles, which could lower SOA mass yields by increasing loss of low-volatile organics to the chamber walls (Kokkola et al., 2014; Zhang et al., 2014; McVay et al., 2014). However, this would not impact comparisons between the control and herbivore-treated SOA yields because seed particles were not used for either set of plant SOA experiments.

\subsection{Global-scale modelling}

An evaluation of the significance of insect damage on atmospheric boreal aerosol was obtained with a global chemical transport model, GLOMAP (Spracklen et al., 2005), to provide a first estimate of the potential scale of the impact. For GLOMAP modelling, $10 \%$ (i.e. $\sim 2.5 \times 10^{6} \mathrm{~km}^{2}$ ) of the total boreal conifer forest was randomly selected to be suffering insect herbivory and a 10-fold increase in monoterpene emissions was assumed in this area. These values $(10 \%$ and 10 fold) were selected as conservative estimates based on our laboratory and field measurements (this study) and recent estimations of biotically stressed tree fractions in Europe (Bergström et al., 2014; Fischer et al., 2012) and are used to present an order-of-magnitude estimate of the effect of insect damage on climate-relevant atmospheric particles. It has been estimated that currently $11 \%$ of northern boreal forests and $19 \%$ of north-central coniferous/mixed forests are al- 
Table 2. Summary of AOD analysed areas (3 × 3-pixel grid). The MPB outbreak areas (MPB-1/2/3) had clear insect outbreaks during analysis period (2002-2012) whereas controls areas (Ctrl-1/2) did not. The map of areas is shown in Fig. S1 and at http://goo.gl/maps/m4lO5.

\begin{tabular}{lll}
\hline Area name & Covered area (lat., long.) & Comments \\
\hline MPB-1 & $52-55^{\circ} \mathrm{N}, 123-126^{\circ} \mathrm{W}$ & $\begin{array}{l}\text { Very strong MPB outbreak starting 2000, } \\
\text { with nearly complete tree mortality by 2006. } \\
\text { About half of the area suffering MPB outbreak } \\
\text { in 2006, located ca. 130 km east of MPB-1. }\end{array}$ \\
MPB-3 & $53-56^{\circ} \mathrm{N}, 118-121^{\circ} \mathrm{W}$ & $\begin{array}{l}\text { MPB migration in the southern part of the } \\
\text { area in 2010-2011, ca. } 330 \mathrm{~km} \text { north of MPB-1. } \\
\text { No significant MPB migration before 2011, } \\
\text { ca. 150 km west of MPB-3. }\end{array}$ \\
Ctrl-1 & $58-61^{\circ} \mathrm{N}, 124-127^{\circ} \mathrm{N}, 130-133^{\circ} \mathrm{W}$ ignificant MPB migration before \\
Ctrl-2 & $55-58^{\circ} \mathrm{N}, 109-112^{\circ} \mathrm{W}$ & 201. 250 km east of MPB-2 \\
\hline
\end{tabular}

ready suffering a significant degree of defoliation $(>25 \%$; Bergström et al., 2014; Fischer et al., 2012).

The GLOMAP aerosol model simulates the emission, transport, microphysical processes and removal of sizeresolved aerosol on a global scale with a horizontal resolution of $2.8^{\circ} \times 2.8^{\circ}$ and 31 vertical levels (Spracklen et al., 2005). The model has been shown to agree well with aerosol observations over the boreal region and to reproduce new particle formation events in Hyytiälä, Finland (Spracklen et al., 2006). It has further been used to demonstrate that emissions of BVOCs from boreal forests can double the regional cloud condensation nuclei concentrations (Spracklen et al., 2008a). We simulated monoterpene emissions according to the GEIA inventory (http://www.geiacenter.org/) and, for computational affordability, made a simplifying assumption that $13 \%$ of their oxidation products form vapours capable of producing SOAs. The constant value used is based on observations in Scandinavian boreal forest (Tunved et al., 2006b). Other aerosol types simulated are sulphate and carbonaceous aerosols from anthropogenic and biomass burning sources (http://aerocom.met.no/Welcome.html) and sea spray. For new particle formation via nucleation, we assumed a linear dependence on the sulphuric acid concentration (so-called activation nucleation; e.g. Sihto et al., 2006). The CCN concentration was calculated from the simulated aerosol size distribution at $1 \mathrm{~km}$ altitude assuming an updraft of $0.3 \mathrm{~m} \mathrm{~s}^{-1}$ and using a physically based droplet activation scheme (Nenes and Seinfeld, 2003).

\subsection{Satellite observations}

The influence of large-scale insect outbreak on local aerosol concentrations was investigated using MODIS (Moderate Resolution Imaging Spectroradiometer) satellite observations. MODIS data were used to analyse aerosol optical depth (AOD) over both insect-outbreak (Kurz et al., 2008a) and less-infested (control) areas mainly located in British Columbia (BC) and Alberta (AB) provinces in Canada. AOD data for selected areas were analysed for an 11-year pe- riod (2002-2012). The MODIS instruments are on board the Terra and Aqua satellites and they have made observations since 2000 and 2002 respectively. MODIS AOD data have been widely used and validated against ground-based measurements (Levy et al., 2010).

The analysed areas (9-pixel grid) are described in detail in Table 2 and a map of the areas can be found in Fig. S1 in the Supplement and at http://goo.gl/maps/m41O5 (see also a web page of Natural Resources Canada (2015): the threat of mountain pine beetle to Canada's boreal forest). The areas are divided into three mountain pine beetle (MPB) outbreak areas (named as MPB-1/2/3) and two control areas (Ctrl-1/2). The areas have been selected based on the MPB migration discovered by Natural Resources Canada (2015). In the first area located in the centre of BC (MPB-1, $330 \times 200 \mathrm{~km}^{2}$ area, west side of city Prince George), the MPB outbreak started to expand in 2000 and most of the pine forest was killed by 2006 based on data from the Ministry of Forests, Lands and Natural Resource Operations (2015). In the MPB2 area (located $130 \mathrm{~km}$ east of MPB-1, at the borderline between $\mathrm{BC}$ and $\mathrm{AB}$ ), about half of the area was already suffering a MPB outbreak in 2006 while the MPB outbreak reached the southern part of the MPB-3 area $(330 \mathrm{~km}$ north of MPB-1, at the borderline between BC and Yukon) from 2010 to 2011. In contrast, there was not significant MPB displacement before the year 2011 in the control areas of Ctrl-1 (170 km west of MPB-3, at the borderline between BC and Yukon) and Ctrl-2 (370 km east of MPB-3, at the borderline between AB and Saskatchewan; Natural Resources Canada, 2015).

There are no big cities inside or near the AOD analysis areas; the most populated towns are Prince George (ca. 72000 inhabitants, MPB-1), Grande Prairie (55 000, MPB-2) and Fort McMurray/Wood Buffalo (66000, Ctrl-2) (Statistics Canada, 2015). The metropolitan areas in $\mathrm{BC}$ and $\mathrm{AB}$ are Vancouver (2.5 million, $300 \mathrm{~km}$ south of MPB-1), Calgary (1.2 million, $350 \mathrm{~km}$ south-east of MPB-2) and Edmonton (1.1 million, $300 \mathrm{~km}$ east of MPB-2 and $190 \mathrm{~km}$ southwest of Ctrl-2). 
Table 3. Temperature standardised $\left(30^{\circ} \mathrm{C}\right)$ emissions of monoterpenes and sesquiterpenes and unstandardised emissions of green leaf volatiles (GLV) and methyl salicylate $\left(\mathrm{ng} \mathrm{g}^{-1}\left(\mathrm{DW}\right.\right.$ needles) $\left.\mathrm{h}^{-1}\right)$ from branch shoots of intact $(n=8)$ and Neodiprion sertifer-damaged $(n=9)$ Pinus sylvestris trees in a forest site in Outokumpu, Finland. Samples were collected on 30 June 2010, approximately 4 weeks after the start of larval feeding. $P$ values of the Mann-Whitney test are given.

\begin{tabular}{|c|c|c|c|c|c|}
\hline & \multicolumn{2}{|c|}{ Control } & \multicolumn{2}{|c|}{$\begin{array}{l}\text { Neodiprion sertifer } \\
\text {-damaged }\end{array}$} & \multirow[t]{2}{*}{ Significance } \\
\hline & Mean & SD & Mean & $\mathrm{SD}$ & \\
\hline \multicolumn{6}{|l|}{ Monoterpenes } \\
\hline Tricyclene & 3.8 & 3.4 & 48.5 & 50.2 & 0.200 \\
\hline$\alpha$-Pinene & 371.7 & 264.9 & 9688.7 & 9815.3 & 0.001 \\
\hline Camphene & 21.2 & 11.8 & 289.9 & 265.0 & $<0.001$ \\
\hline Sabinene & 47.7 & 38.0 & 295.2 & 305.6 & 0.011 \\
\hline$\beta$-Pinene & 119.2 & 114.2 & 2092.5 & 2900.8 & 0.036 \\
\hline Myrcene & 371.6 & 462.9 & 6461.3 & 8841.9 & 0.006 \\
\hline$\Delta 3$-Carene & 613.8 & 715.8 & 3130.0 & 4017.0 & 0.321 \\
\hline Limonene & 1703.4 & 4203.7 & 13154.5 & 16704.7 & 0.004 \\
\hline$\beta$-Phellandrene ${ }^{\mathrm{a}}$ & 309.7 & 375.7 & 3482.6 & 4934.0 & 0.036 \\
\hline 1,8-Cineol & 20.8 & 18.6 & 81.8 & 102.0 & 0.321 \\
\hline$\gamma$-Terpinene & 7.6 & 6.9 & 48.3 & 36.9 & 0.001 \\
\hline Terpinolene & 39.6 & 53.7 & 417.5 & 388.8 & 0.001 \\
\hline Linalool & 13.6 & 13.3 & 219.6 & 247.8 & 0.011 \\
\hline Camphor & 0.3 & 0.8 & 0.9 & 2.8 & 1.000 \\
\hline Borneol & 0.5 & 0.9 & 3.3 & 3.4 & 0.059 \\
\hline Terpinen-4-ol & 0.9 & 1.4 & 7.1 & 14.6 & 0.815 \\
\hline$\alpha$-Terpineol & 1.7 & 3.2 & - & - & 0.423 \\
\hline Bornyl acetate & 3.4 & 2.8 & 63.1 & 21.0 & 0.004 \\
\hline Total monoterpenes & 3650.7 & 4625.3 & 39488.6 & 34027.9 & $<0.001$ \\
\hline \multicolumn{6}{|l|}{ Sesquiterpenes } \\
\hline$\alpha$-Copaene & 0.3 & 0.3 & 10.8 & 17.1 & 0.002 \\
\hline Longifolene & 1.8 & 1.9 & 45.3 & 66.8 & 0.006 \\
\hline$(E)$ - $\beta$-Farnesene & 12.2 & 8.4 & 181.8 & 252.0 & $<0.001$ \\
\hline (E)- $\beta$-Caryophyllene & 1.0 & 1.3 & 49.0 & 58.7 & $<0.001$ \\
\hline$\alpha$-Humulene & 0.2 & 0.4 & 8.4 & 9.5 & 0.002 \\
\hline$\delta$-Cadinene & 3.0 & 1.8 & 43.6 & 35.7 & $<0.001$ \\
\hline$\alpha$-Cubebene ${ }^{\mathrm{b}}$ & 0.2 & 0.4 & 4.1 & 10.3 & 0.606 \\
\hline$\alpha$-Longipinene $\mathrm{e}^{\mathrm{b}}$ & 0.6 & 1.2 & 56.2 & 112.0 & 0.002 \\
\hline$\beta$-Bourbonene ${ }^{\mathrm{b}}$ & 2.4 & 5.6 & 32.5 & 42.7 & 0.006 \\
\hline$\beta$-Cubebene ${ }^{\mathrm{b}}$ & 0.2 & 0.6 & 0.3 & 0.8 & 1.000 \\
\hline$\alpha$-Amorphene ${ }^{\mathrm{b}}$ & $<0.1$ & $<0.1$ & 11.7 & 14.8 & 0.001 \\
\hline$(E, E)-\alpha$-Farnesene $\mathrm{e}^{\mathrm{b}}$ & 2.7 & 4.4 & 30.5 & 59.8 & 0.743 \\
\hline$\alpha$-Muurolene ${ }^{\mathrm{b}}$ & 0.6 & 0.8 & 19.4 & 27.4 & 0.006 \\
\hline Unknown & 0.3 & 0.5 & 18.4 & 18.6 & 0.002 \\
\hline bis- $\alpha$-Bisabolene ${ }^{b}$ & 0.1 & 0.4 & 5.2 & 9.1 & 0.200 \\
\hline Total sesquiterpenes & 25.7 & 13.2 & 517.1 & 560.3 & $<0.001$ \\
\hline Total terpenes & 3676.3 & 4625.8 & 40005.7 & 34409.0 & $<0.001$ \\
\hline \multicolumn{6}{|l|}{ Aromatics } \\
\hline Methyl salicylate & 0.2 & 0.6 & 1.2 & 2.5 & 0.481 \\
\hline \multicolumn{6}{|l|}{ GLVs } \\
\hline (E)-2-Hexenal & - & - & 18.3 & 31.2 & 0.277 \\
\hline (Z)-3-Hexanol & - & - & 3.9 & 8.3 & 0.481 \\
\hline 1-Octen-3-ol & - & - & 13.0 & 38.9 & 0.743 \\
\hline (Z)-3-Hexenyl-acetat & 0.7 & 2.0 & 19.8 & 38.8 & 0.423 \\
\hline Nonanal & 11.0 & 11.5 & 10.5 & 18.1 & 0.481 \\
\hline (Z)-3-Hexenyl-butyrate & - & - & 2.0 & 6.0 & 0.743 \\
\hline (Z)-3-Hexenyl-tiglate & - & - & 0.1 & 0.3 & 0.743 \\
\hline Total GLVs & 11.7 & 11.5 & 68.7 & 93.4 & 0.606 \\
\hline
\end{tabular}

${ }^{a}$ Emission calculated using sabinene as a standard; ${ }^{b}$ longifolene as a standard. Dash (-) indicates that the compound was not detected. 
We have excluded days with any evidence of forest fire aerosols in our analysis to isolate the effects of herbivore outbreak on AOD from the effects of forest fires (list of excluded days in Table S1 in the Supplement). Fire days were selected for exclusion by carefully analysing MODIS Terra and Aqua AOD measurements day by day, focusing on an area that extended over the entire analysis area to see if there was any indication of confounding smoke aerosol. Figure S2 gives examples of included and excluded days. The region used for this exclusion analysis was larger than that shown in the figure, but for clarity this figure has been reduced to $9 \times 9$ pixels. It is evident that smoke does not affect our focus area; however, these days were still excluded due to the AOD levels being clearly elevated in the neighbouring pixels, likely due to smoke from forest fires. As a result of this very strict screening, a substantial amount of measurements were excluded (for instance in August 2010) to form the "smokefree" set of MODIS data.

Changes in AOD were evaluated with analysis of covariance (ANCOVA). The analysis was performed with SPSS 21 (SPSS Inc., Chicago, IL). In the first phase, the ANCOVA model consisted of three predictor values: year and study area as categorical variables and daily temperature maximum as a continuous variable. Mean daily temperatures in $\mathrm{Au}-$ gust were calculated using NCEP Reanalysis data (Kalnay et al., 1996) provided by the NOAA/OAR/ESRL PSD, Boulder, Colorado, USA (NOAA, 2014). Here, the temperature range is narrow and thus the effect of temperature could be approximated as a linear effect in ANCOVA. Temperature is known to affect VOC emission from plants (Guenther et al., 1993; Helmig et al., 2006) and hence affects SOA formation. However, temperature has been suggested to be a reducing factor for new particle formation and growth (e.g. Hamed et al., 2007, and references therein; Mikkonen et al., 2011). Therefore, the effect of temperature (daily maximum) has been taken into account in AOD analysis results presented here.

An alternate approach to AOD data analysis was to hone in on two shorter time periods (period I: 2003-2005; period II: 2008-2010) in order to highlight the differences between study areas within the worst outbreaks. Pairwise statistical analysis were conducted for those two time periods. In this analysis, the predictor variables were only study area and daily temperature maximum.

\section{Results and discussion}

Our results represent the first synthesis of small-scale field and laboratory measurements with large-scale satellite and regional modelling studies to investigate the impacts of herbivore outbreaks on biogenic SOA formation. In this section, we will first compare VOC emission rates from control and herbivore-infested trees at a field site in eastern Finland and from laboratory experiments. Then, we present results from

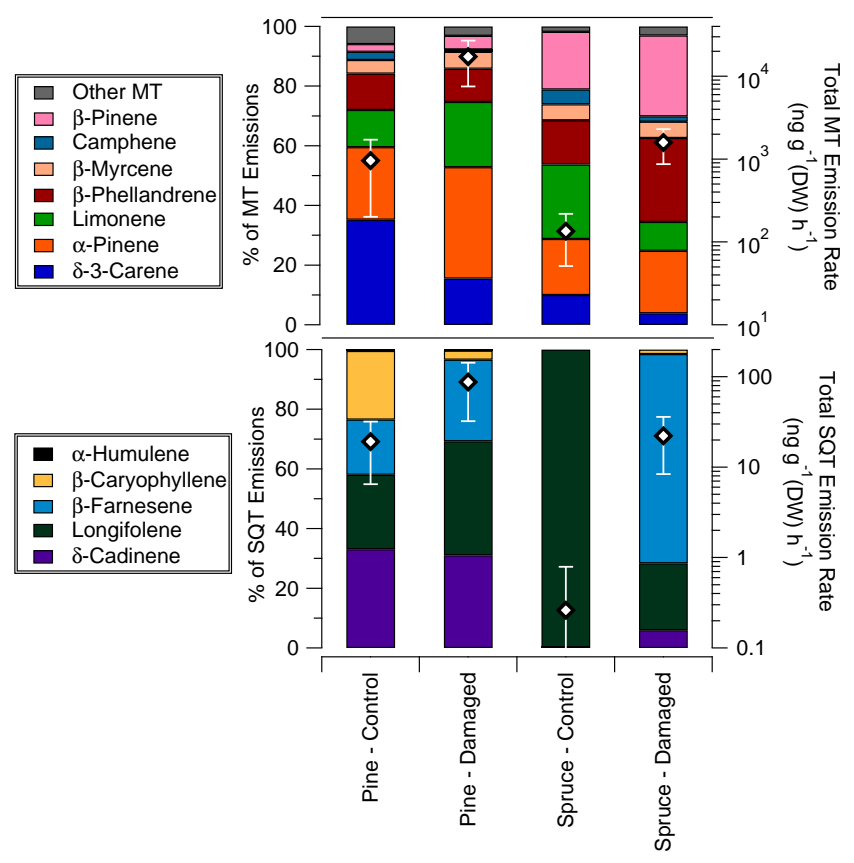

Figure 2. Monoterpenes (MTs, upper panel) and sesquiterpenes (SQTs, lower panel) emission profiles (proportions of total MT/SQT emissions) from control and insect-damaged Scots pine and Norway spruce seedlings (left axis). The diamonds show total MT and SQT emission rates per needle dry mass (right axes). The error bars represent the standard deviation of the averaged value. The results are averages of all 1-day experiments.

controlled laboratory experiments where the effects of biotic stress on SOA formation were tested on two different tree species. The remaining sections discuss the larger-scale regional implications of herbivore outbreaks on SOA formation. We present results from a regional model investigating the effect of an herbivore outbreak on particle mass loading and $\mathrm{CCN}$ number in boreal forests. Finally, we provide a case study analysis of satellite AOD to investigate the effect of the largest recorded mountain pine beetle outbreak in the Canadian Rockies.

\subsection{VOC emissions}

In the field experiments, we studied the effect of insect herbivory on VOC emission rates of young Scots pine (Pinus sylvestris) saplings in a pine sawfly (Neodiprion sertifer) outbreak area of a forest stand (Outokumpu, Finland). The emission rates (Table 3) of total monoterpenes (MTs) and sesquiterpenes (SQTs) of insect-damaged trees were significantly increased $(p<0.001)$ compared to control trees: 11 -fold and 20-fold increases were observed respectively. Limonene was the most abundant MT, but $\alpha$-pinene had the most distinctive response to insect feeding with a 26-fold increase in emissions. In contrast, emission rates of C6 GLV compounds were not significantly affected. 
Table 4. VOC emission rates per gram of needle dry mass $\left(\mathrm{ng} \mathrm{gDW}^{-1} \mathrm{~h}^{-1}\right)$ from intact and Hylobius abietis-damaged Scots pine seedlings (chamber experiments). Average emission rates with standard deviations (SD) from four different experiments are shown. $P$ values of the Mann-Whitney test are given.

\begin{tabular}{|c|c|c|c|c|c|}
\hline \multirow[b]{3}{*}{ Compound name } & \multicolumn{4}{|c|}{ Emission rates $\left(\mathrm{ng} \mathrm{gDW}^{-1} \mathrm{~h}^{-1}\right)$} & \multirow{3}{*}{ Significance } \\
\hline & \multicolumn{2}{|c|}{ Intact seedlings } & \multicolumn{2}{|c|}{ Damaged seedlings } & \\
\hline & Mean & SD & Mean & SD & \\
\hline$\alpha$-Pinene & 233.0 & 248.3 & 6425.6 & 3256.0 & $<0.001$ \\
\hline Limonene & 119.8 & 151.7 & 3776.1 & 2498.8 & $<0.001$ \\
\hline 3-Carene & 337.9 & 240.9 & 2676.4 & 2893.0 & 0.021 \\
\hline$\beta$-Phellandrene & 116.6 & 174.3 & 1915.5 & 2355.1 & $<0.001$ \\
\hline$\beta$-Myrcene & 44.1 & 32.9 & 976.4 & 851.1 & $<0.001$ \\
\hline$\beta$-Pinene & 25.0 & 21.6 & 788.7 & 446.4 & $<0.001$ \\
\hline Terpinolene & 11.2 & 10.8 & 214.4 & 258.5 & $<0.001$ \\
\hline Camphene & 26.1 & 23.4 & 137.5 & 108.6 & 0.001 \\
\hline Sabinene & 20.2 & 18.9 & 144.2 & 143.1 & 0.006 \\
\hline 1,8-Cineole & 16.0 & 22.0 & 95.9 & 58.1 & $<0.001$ \\
\hline$\gamma$-Terpinene & 3.2 & 3.0 & 33.0 & 36.3 & $<0.001$ \\
\hline Bornyl acetate & 4.3 & 4.9 & 22.6 & 11.4 & $<0.001$ \\
\hline Linalool & - & - & 12.8 & 19.1 & 0.006 \\
\hline Camphor & 1.1 & 3.7 & 5.3 & 7.7 & 0.244 \\
\hline Terpinen-4-ol & 0.1 & 0.4 & 4.7 & 5.5 & $<0.001$ \\
\hline Borneol & 0.2 & 0.6 & 4.4 & 4.5 & $<0.001$ \\
\hline$\alpha$-Terpineol & 0.4 & 1.2 & 1.7 & 3.5 & 0.478 \\
\hline Longifolene $^{\mathrm{a}}$ & 4.8 & 4.5 & 33.4 & 24.9 & $<0.001$ \\
\hline$(E)-\beta$-Farnesene ${ }^{\mathrm{a}}$ & 3.5 & 5.6 & 23.8 & 26.1 & $<0.001$ \\
\hline$\delta$-Cadinene ${ }^{\mathrm{a}}$ & 6.3 & 6.0 & 27.1 & 12.2 & $<0.001$ \\
\hline$(E)-\beta$-Caryophyllene ${ }^{\mathrm{a}}$ & 4.4 & 5.2 & 2.7 & 4.7 & 0.280 \\
\hline$\alpha$-Humulene ${ }^{\mathrm{a}}$ & 0.1 & 0.3 & 0.3 & 1.1 & 0.963 \\
\hline Sum of monoterpenes & 959.3 & 758.5 & 17235.3 & 9710.2 & $<0.001$ \\
\hline Sum of sesquiterpenes & 19.1 & 12.7 & 87.3 & 55.1 & $<0.001$ \\
\hline Sum of terpenes & 978.4 & 771.1 & 17322.7 & 9765.3 & $<0.001$ \\
\hline
\end{tabular}

In the laboratory chamber experiments (Table 1), bark of Scots pine and Norway spruce seedlings was damaged by large pine weevils (Hylobius abietis), a major pest of conifer seedlings in northern Europe. Tables 4 and 5 show VOC emission rates from the control and insect-damaged Scots pine and Norway spruce seedlings respectively. In both cases, VOC emissions from the insect-damaged seedlings were significantly higher than from the control seedlings $(p<0.001)$. The average MT emission rates of the damaged seedlings were approximately 12 (spruce) to 18 (pine) and SQT emission rates 5 (pine) to 85 (spruce) times higher than the controls. The most abundant compounds of Scots pine emissions (control and damaged) were $\alpha$-pinene, limonene, 3carene and $\beta$-phellandrene and for Norway spruce $\alpha$-pinene, limonene, $\beta$-phellandrene and $\beta$-pinene. The identified SQT fractions represented only $0.2-2 \%$ of all terpenes (both plants and cases).

The current study also showed changes in the relative proportions of measured compounds as shown in Fig. 2. The in- sect damage changed the profile of Scots pine emissions by promoting MT emissions of the $\alpha$-pinene, limonene and $\beta$ pinene together with SQT emissions of longifolene and $(E)$ $\beta$-farnesene. In contrast, a clear decrease was observed in 3 -carene fraction. Increased emissions of the same monoterpenes ( $\alpha$-pinene, limonene and $\beta$-pinene) were reported from pine seedling foliage after pine weevil damage and longifolene emission was increased from the feeding site on the pine stem (Heijari et al., 2011). However, lower emissions of 3carene from damaged seedlings might also indicate a lower proportion of "3-carene type" Scots pine seedlings (Semiz et al., 2007) in pine weevil treatment.

For Norway spruce, there were increases in relative emissions of the main MT components $\beta$-phellandrene, $\beta$-pinene and $\alpha$-pinene and a minor component 1,8 -cineole. SQT emissions of longifolene, $(E)$ - $\beta$-farnesene and $\delta$-cadinene were clearly increased after insect damage (ca. 85 fold). These levels are similar to emissions reported in a study by Blande et al. (2009) on Norway spruce damaged by pine weevils where 
Table 5. VOC emission rates per gram of needle dry mass from intact and Hylobius abietis-damaged Norway spruce seedlings (chamber experiments). Average emission rates with standard deviations (SD) from two different experiments are shown. $P$ values of the MannWhitney test are given.

\begin{tabular}{|c|c|c|c|c|c|}
\hline \multirow[b]{3}{*}{ Compound name } & \multicolumn{4}{|c|}{ Emission rates $\left(\mathrm{ng} \mathrm{gDW}^{-1} \mathrm{~h}^{-1}\right)$} & \multirow{3}{*}{ Significance } \\
\hline & \multicolumn{2}{|c|}{ Intact seedlings } & \multicolumn{2}{|c|}{ Damaged seedlings } & \\
\hline & Mean & SD & Mean & SD & \\
\hline$\alpha$-Pinene & 25.4 & 15.5 & 331.7 & 138.4 & $<0.001$ \\
\hline Limonene & 33.6 & 18.2 & 154.2 & 97.4 & $<0.001$ \\
\hline 3-Carene & 13.4 & 17.7 & 61.9 & 27.6 & 0.003 \\
\hline$\beta$-Phellandrene & 20.0 & 14.0 & 446.0 & 246.3 & $<0.001$ \\
\hline$\beta$-Myrcene & 7.2 & 4.1 & 87.1 & 44.0 & $<0.001$ \\
\hline$\beta$-Pinene & 26.1 & 19.2 & 429.6 & 170.6 & $<0.001$ \\
\hline Terpinolene & - & - & 5.0 & 4.9 & 0.009 \\
\hline Camphene & 6.7 & 2.8 & 28.2 & 7.5 & $<0.001$ \\
\hline Sabinene & - & - & 3.9 & 11.0 & 0.346 \\
\hline 1,8-Cineole & 0.5 & 1.1 & 17.9 & 6.9 & $<0.001$ \\
\hline$\gamma$-Terpinene & - & - & 1.7 & 0.6 & $<0.001$ \\
\hline Bornyl acetate & 1.9 & 1.4 & 6.7 & 2.8 & $<0.001$ \\
\hline Linalool & - & - & 12.2 & 13.4 & 0.003 \\
\hline Camphor & - & - & - & - & $\mathrm{NaN}$ \\
\hline Terpinen-4-ol & - & - & 0.2 & 0.6 & 0.346 \\
\hline Borneol & - & - & 0.4 & 0.7 & 0.144 \\
\hline$\alpha$-Terpineol & - & - & 0.5 & 1.5 & 0.346 \\
\hline Longifolene $^{\mathrm{a}}$ & 0.3 & 0.5 & 5.0 & 2.5 & 0.002 \\
\hline$(E)-\beta$-Farnesene ${ }^{\mathrm{a}}$ & - & - & 15.6 & 14.9 & $<0.001$ \\
\hline$\delta$-Cadinene $\mathrm{e}^{\mathrm{a}}$ & - & - & 1.3 & 1.2 & 0.009 \\
\hline$(E)-\beta$-Caryophyllene ${ }^{\mathrm{a}}$ & - & - & 0.3 & 0.9 & 0.346 \\
\hline$\alpha$-Humulene ${ }^{\mathrm{a}}$ & - & - & - & - & $\mathrm{NaN}$ \\
\hline Sum monoterpenes & 134.7 & 83.5 & 1587.1 & 716.1 & $<0.001$ \\
\hline Sum sesquiterpenes & 0.3 & 0.5 & 22.2 & 13.8 & $<0.001$ \\
\hline Sum terpenes & 135.0 & 84.1 & 1609.3 & 729.9 & $<0.001$ \\
\hline
\end{tabular}

a Sesquiterpenes. Dash (-) indicates that the compound was not detected (i.e. concentration or below detection limit ca. $\left.0.1 \mathrm{ng} \mathrm{gDW}^{-1} \mathrm{~h}^{-1}\right)$.

large MT emissions were due to resin flow at feeding sites on the branches.

We conducted our laboratory experiment with young seedlings due to practical restraints for a laboratory study, but these results should be representative of emissions of full grown forest trees because monoterpene composition of needles and wood of Scots pine are under strong genetic control. A 19-year monitoring study indicated that seedlings of Scots pine provenances at the age of 4 and 12 months has similar composition as the fresh cut stumps 19 years later (Kivimäenpää et al., 2012).

The field and laboratory results show that insect damage induced significant changes in the VOC blends emitted by both conifer species. In addition to increasing emissions, there was induction of several highly reactive compounds, including limonene, $\beta$-phellandrene, $\beta$-myrcene and $(E)$ - $\beta$ farnesene, that could have a significant effect on SOA formation processes (Bonn and Moortgat, 2003), e.g. by reducing nucleation threshold and increasing SOA mass.

\subsection{SOA formation}

SOA formation by oxidation of VOCs emitted from Scots pine and Norway spruce seedlings was studied in a continuous flow reactor system (Fig. 1) in which VOCs emitted from Scots pine or Norway spruce seedlings were channelled into a separate reaction chamber and mixed with ozone-enriched air (50 or $200 \mathrm{ppb}$ ). Figure 3 shows SOA formation results as a function of the hour of day for the experiments with Scots pine seedlings at the ozone level of $50 \mathrm{ppb}$. When the air from the headspace of herbivore-damaged seedlings was mixed with ozone-rich air, intensive SOA formation was observed $15-20 \mathrm{~min}$ after the start of ozone introduction. The SOA mass peaked about $3 \mathrm{~h}$ after the start of the ozone addition; it then decreased during the next $9 \mathrm{~h}$ before stabilising. It should be noted that the introduction of plant-emitted VOCs to the chamber began $60 \mathrm{~min}$ before ozone addition and therefore the initial VOC concentrations were higher than later in the trials. During night periods (from 24:00 to 

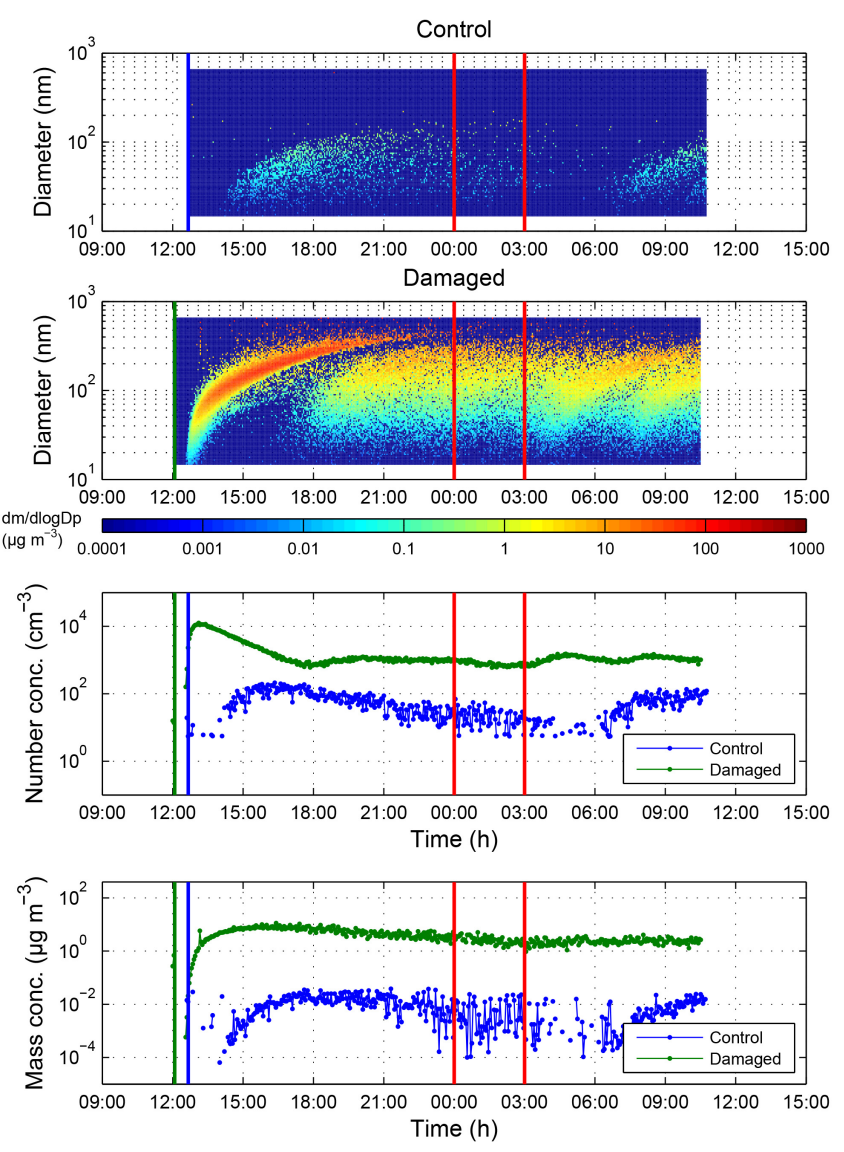

Figure 3. SOA formation via ozonolysis of VOCs emitted from Scots pine seedlings in atmospheres enriched with $50 \mathrm{ppb} \mathrm{O}_{3}$. SOA particle mass size distribution as a function of time (hour of day) from the control (first panel) and the insect-stressed experiment (second panel) experiments; total number (third panel) and mass (fourth panel) concentrations. Start times of the ozone addition are indicated by blue (control) and green (damaged) vertical lines. Lights were off over the plant chamber from 24:00 to 03:00 (indicated by red vertical lines). Note that introduction of plant-emitted VOCs to the chamber was started $1 \mathrm{~h}$ before ozone addition and therefore more intensive particle formation can be observed at the beginning of the trials.

03:00) the lights over plants were off and SOA formation was lower due to reduced VOC emissions (approx. $50 \%$ of day values); however, clear SOA formation was still observed. In contrast, only a very weak SOA formation (roughly 500-fold lower in mass) can be observed in experiments with control plants. Furthermore, particle formation was observed with a longer delay after ozone addition than in herbivore-damage experiments and particle concentrations were very low during night periods.

Experiments at the ozone concentration of $200 \mathrm{ppb}$ showed very similar results for Scots pine and Norway spruce seedlings as shown in Fig. 4. For herbivore-damaged seedlings, clear and intensive new particle formation was ob- served after ozone introduction, whereas only very weak particle formation can be observed in the control experiments. Moreover, lower particle production was observed during the night when lights were off and the VOC emissions were lower.

VOC concentrations were also measured at the outlet of the chamber to evaluate fate of different VOC compounds. The results showed that most of the compounds that were totally consumed in the reaction chamber (e.g. limonene, $\beta$ myrcene, terpinolene, $\beta$-phellandrene, $(E)-\beta$-farnesene, $\delta$ cadinene) had two or more carbon double bonds $(\mathrm{C}=\mathrm{C})$ making them very reactive with ozone (Kroll and Seinfeld, 2008). Compounds with more than one double bond contribute substantially to SOA growth because of the secondgeneration products that can be formed by further oxidation (Ng et al., 2006).

Figure 5 shows SOA mass yields (ratio of formed SOA mass and reacted VOC concentrations) as a function of formed organic mass. Average SOA mass yields vary between 0.1 and $3 \%$ in control experiments and 5 and $40 \%$ in insect-damage experiments (overall averages 1 and $18 \%$ respectively). A clear reduction of SOA mass yields can be seen with decreasing SOA mass, a similar reduction has typically been observed in SOA formation experiments (Odum et al., 1996; Shilling et al., 2008; Hao et al., 2011). Based on gas/particle partitioning theories and models and smog chamber experiments, the aerosol yield strongly depends on the organic particulate mass (Odum et al., 1996; Pankow, 1994; Song et al., 2005). The organic particulate mass acts as a medium into which oxidation products can be absorbed and hence higher organic particulate mass increases aerosol mass yields. For comparison, Mentel et al. (2013) studied SOA formation from emissions of common temperate and Boreal forest trees (pine, spruce, birch and beech) and they reported yields between 17 and $33 \%$ from experiments with stress-induced emissions, which are significantly higher than obtained experiments containing mainly MTs (4$6 \%$ ). It should be noted that recent studies have shown that the depletion of very-low-volatile VOCs to chamber walls could lead to a significant underestimation of SOA formation yields determined from chamber experiments (Kokkola et al., 2014; Zhang et al., 2014). Furthermore, the SOA mass yields determined from different chambers under different conditions can vary widely (Lee et al., 2006; Shilling et al., 2008; Mentel et al., 2013; Hao et al., 2011) and therefore it is not straightforward to assess a suitable yield values for model calculations. In this study, we have used a fixed $13 \%$ yield (all cases) in the GLOMAP modelling as is the common established practice for regional to globalscale modelling applications. This value is also consistent with our insect-damage experiments (overall averages $18 \%$ ). This fixed yield value might overestimate SOA formation in control areas with lower VOC and SOA mass concentrations, so the potential effect observed here would be a lower estimate of the potential effect. 

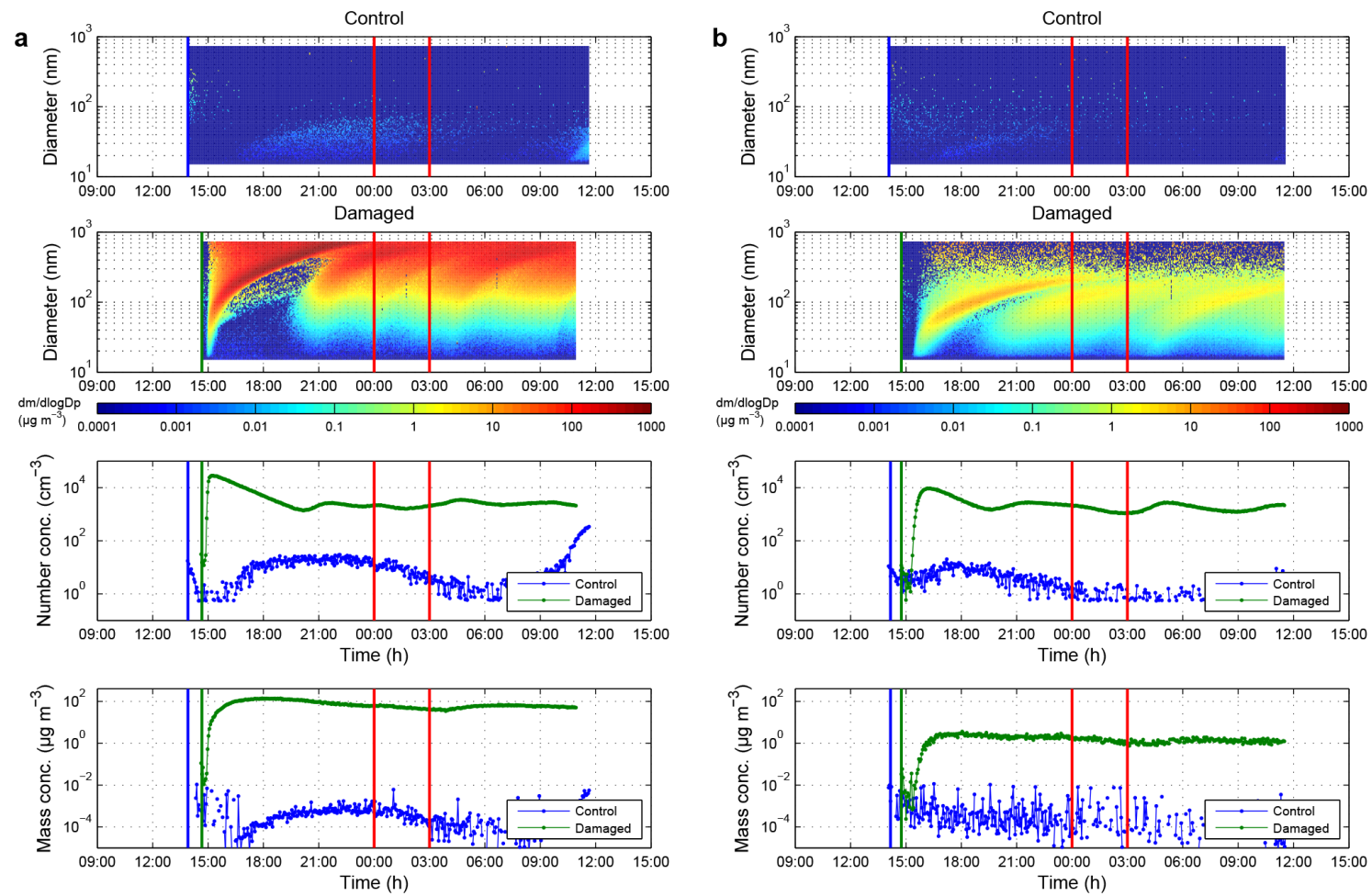

Figure 4. SOA formation via ozonolysis of VOCs emitted seedlings in atmospheres enriched with $\mathrm{O}_{3}$. SOA particle mass particle size distributions and corresponding total concentrations as a function of time (hour of day) for (a) Scots pine and (b) Norway spruce experiments at $200 \mathrm{ppb}$ of $\mathrm{O}_{3}$ : mass size distributions from control (first panel) and insect-stressed (second panel) experiments; total number (third panel) and mass (fourth panel) concentrations. Start times of the ozone addition are indicated by blue and green vertical lines. Lights were off over the plant chamber from 24:00 to 03:00 (indicated by red vertical lines). Note that introduction of plant-emitted VOCs to the chamber was started $1-1.5 \mathrm{~h}$ before ozone addition and therefore very intensive particle formation can be observed at the beginning of the trials.

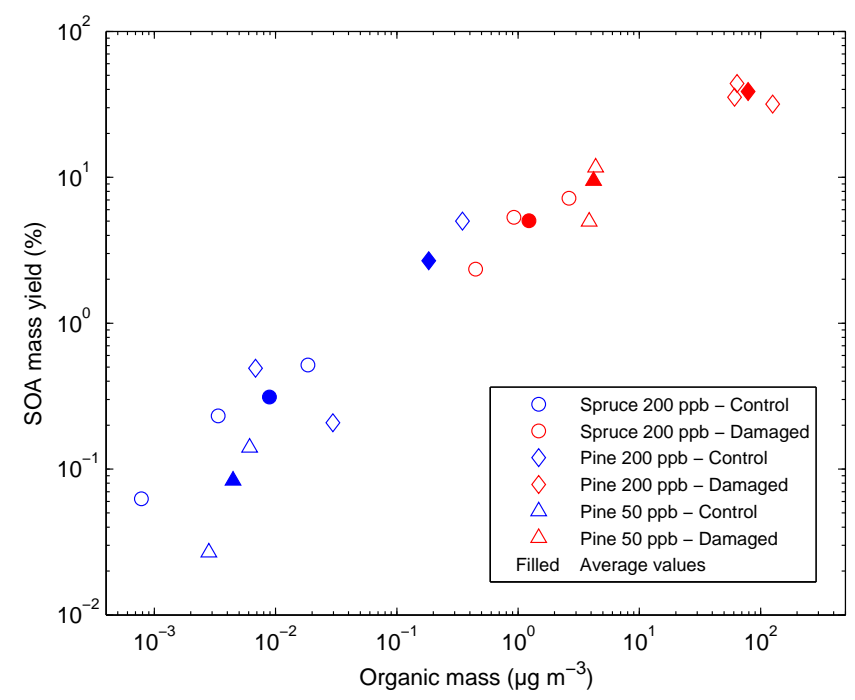

Figure 5. SOA mass yields (i.e. ratio of formed SOAs and reacted VOC concentrations) as a function of formed organic mass. Blue marks denotes control and red insect-damage experiments, filled marks average values of 1-day experiments.
The results from 12 different chamber experiments are summarised in Table 6 (average results from the start of the trial at 13:00-15:00 until the next morning at 09:00). In general, feeding by $H$. abietis weevils increased average VOC emissions from seedlings by 10-50 fold, and ozonolysis of VOCs at 50-200 ppb of $\mathrm{O}_{3}$ increased total number and mass concentrations of SOA particles by $20-70$ fold and $200-1000$ fold respectively. In addition, average SOA mass yields increased from $0.1-3$ to $5-40 \%$ after herbivore feeding. A more pronounced enhancement in SOA formation was observed after herbivore feeding than after increase of ozone concentration from 50 to $200 \mathrm{ppb}$. This suggests that in the future, insect outbreak-related changes in VOC emissions might have regionally a more important role in the formation rate of SOAs than increases in tropospheric ozone levels (Sitch et al., 2007).

\subsection{Global-scale modelling}

We used a simplified SOA formation set-up within the GLOMAP model to assess whether the large-scale insect outbreaks could potentially impact Earth's climate. The model set-up is summarised in Fig. 6a: 10\% of the total boreal 

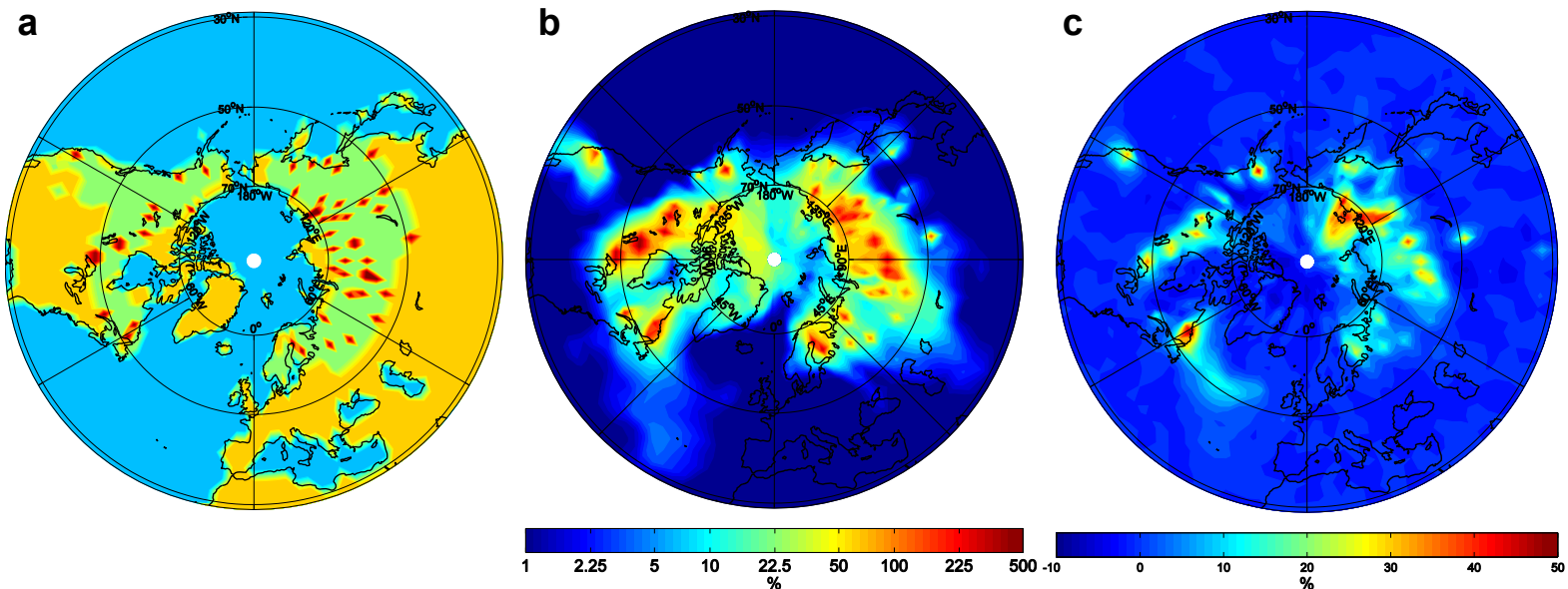

Figure 6. Set-up of global model and simulated changes in aerosol concentrations. (a) Randomly selected $10 \%$ insect-stressed areas (red, 10 -fold increase in monoterpene emissions) of the total boreal conifer forest region (green); (b) modelled relative change in total particulate mass concentration at the surface layer and (c) modelled relative change in $\mathrm{CCN}$ concentration at $0.2 \%$ supersaturation at cloud base (1 km altitude).

Table 6. Summary of the main BVOC and SOA parameters from tests with undamaged control and insect-damaged plants (total of 12 chamber experiments, see Table S1). The total terpene, monoterpene and sesquiterpene (SQT) concentrations were measured at the inlet of the reaction chamber. SOA number (Ntot) and mass (Mtot) concentrations, average size of particles (GMD, geometric number mean diameter) and SOA mass yields were measured at the reactor outlet.

\begin{tabular}{|c|c|c|c|c|c|c|c|c|c|}
\hline \multirow[b]{2}{*}{ Parameter } & \multicolumn{3}{|c|}{ Pine, $\mathrm{O}_{3} 50 \mathrm{ppb}$} & \multicolumn{3}{|c|}{ Pine, $\mathrm{O}_{3} 200 \mathrm{ppb}$} & \multicolumn{3}{|c|}{ Spruce, $\mathrm{O}_{3} 200 \mathrm{ppb}$} \\
\hline & Control & Damaged & Dam./Contr. & Control & Damaged & Dam./Contr. & Control & Damaged & Dam./Contr. \\
\hline Terpenes (ppb) & $5.0 \pm 2.6$ & $43 \pm 26$ & 8.6 & $1.3 \pm 1.0$ & $64 \pm 36$ & 51 & $0.50 \pm 0.34$ & $5.5 \pm 2.3$ & 11 \\
\hline Monoterpenes (ppb) & $4.9 \pm 2.6$ & $43 \pm 26$ & 8.7 & $1.2 \pm 1.0$ & $64 \pm 36$ & 52 & $0.50 \pm 0.34$ & $5.4 \pm 2.3$ & 11 \\
\hline SQT (ppt) & $100 \pm 40$ & $180 \pm 120$ & 1.9 & $20 \pm 20$ & $210 \pm 100$ & 11 & $0.7 \pm 1.4$ & $70 \pm 50$ & 100 \\
\hline Ntot $\left(\mathrm{cm}^{-3}\right)$ & $51 \pm 49$ & $1600 \pm 1900$ & 32 & $250 \pm 440$ & $4600 \pm 5500$ & 18 & $28 \pm 66$ & $2100 \pm 1600$ & 73 \\
\hline $\operatorname{Mtot}\left(\mu \mathrm{g} \mathrm{m}^{-3}\right)$ & $0.01 \pm 0.07$ & $5.9 \pm 3.7$ & 490 & $0.08 \pm 0.18$ & $84 \pm 40$ & 1000 & $0.005 \pm 0.021$ & $1.2 \pm 0.7$ & 230 \\
\hline GMD (nm) & $49 \pm 21$ & $110 \pm 40$ & 2.3 & $39 \pm 17$ & $210 \pm 82$ & 5.3 & $55 \pm 53$ & $56 \pm 19$ & 1.0 \\
\hline SOA yield $(\%)$ & $0.08 \pm 0.08$ & $9.5 \pm 7.7$ & 110 & $2.7 \pm 4.9$ & $39 \pm 12$ & 15 & $0.31 \pm 0.38$ & $5.0 \pm 2.6$ & 16 \\
\hline
\end{tabular}

$\mathrm{Dam} . /$ Control is the relative difference. Values are average results ( \pm standard deviation) from two different $\mathrm{SOA}$ formation experiments (only one for pine control at 50 ppb $\mathrm{O}_{3}$ ) lasting from 13:00 to 15:00 until 09:00 the next morning.

conifer forest suffered insect herbivory with a 10 -fold increase in monoterpene emissions in outbreak areas. Note that the simulations do not include sesquiterpene emissions, as they are not incorporated in the model version used here. Thus the results presented here likely represent a conservative lower bound of the potential impact as any increases in sesquiterpene emissions would serve to increase SOA yields even more dramatically. Furthermore, D'Andrea et al. (2015) have recently estimated that in the boreal forest region monoterpenes are typically responsible for up to over $80 \%$ of SOA formation, while sesquiterpenes play a much less significant role. We do not expect this shortcoming to impact our conclusions, which are intended to merely indicate whether insect herbivory could be of regional importance and thus merit more detailed model studies in the future. A 10-fold increase in monoterpene emissions in $10 \%$ of the total boreal area are conservative estimates based on field (Table 3) and laboratory (Tables 4 and 5) measurements and an ICP Forests Report (Fischer et al., 2012) re- spectively. This local increase in monoterpene emissions is much higher than has previously been estimated to result from changes in climate variables from the late 20th century to 2100 (global increase of $19-119 \%$; Heald et al., 2008; Tsigaridis and Kanakidou, 2007). Heald et al. (2008) also predict that changes in SOA formation from climate change alone (temperature, oxidative capacity and removal rates) is very small, and thus the effect of increasing temperature is not simulated here.

Relative changes in total particulate mass (Fig. 6b) and CCN concentration (Fig. 6c) were simulated. While the largest simulated relative changes in total particulate mass (up to $\sim 480 \%$ increases) were limited to the insect-infested areas (Fig. 6b), the particle mass increased more than $50 \%$ for an area of $8.7 \times 10^{6} \mathrm{~km}^{2}$, i.e. $\sim 3.5$ times that damaged by insects. These large regional increases reflect the dominance of biogenic aerosol precursors and thus the susceptibility of aerosol properties to changes in biogenic VOCs in this area. Meanwhile, $\mathrm{CCN}$ concentration increased over 

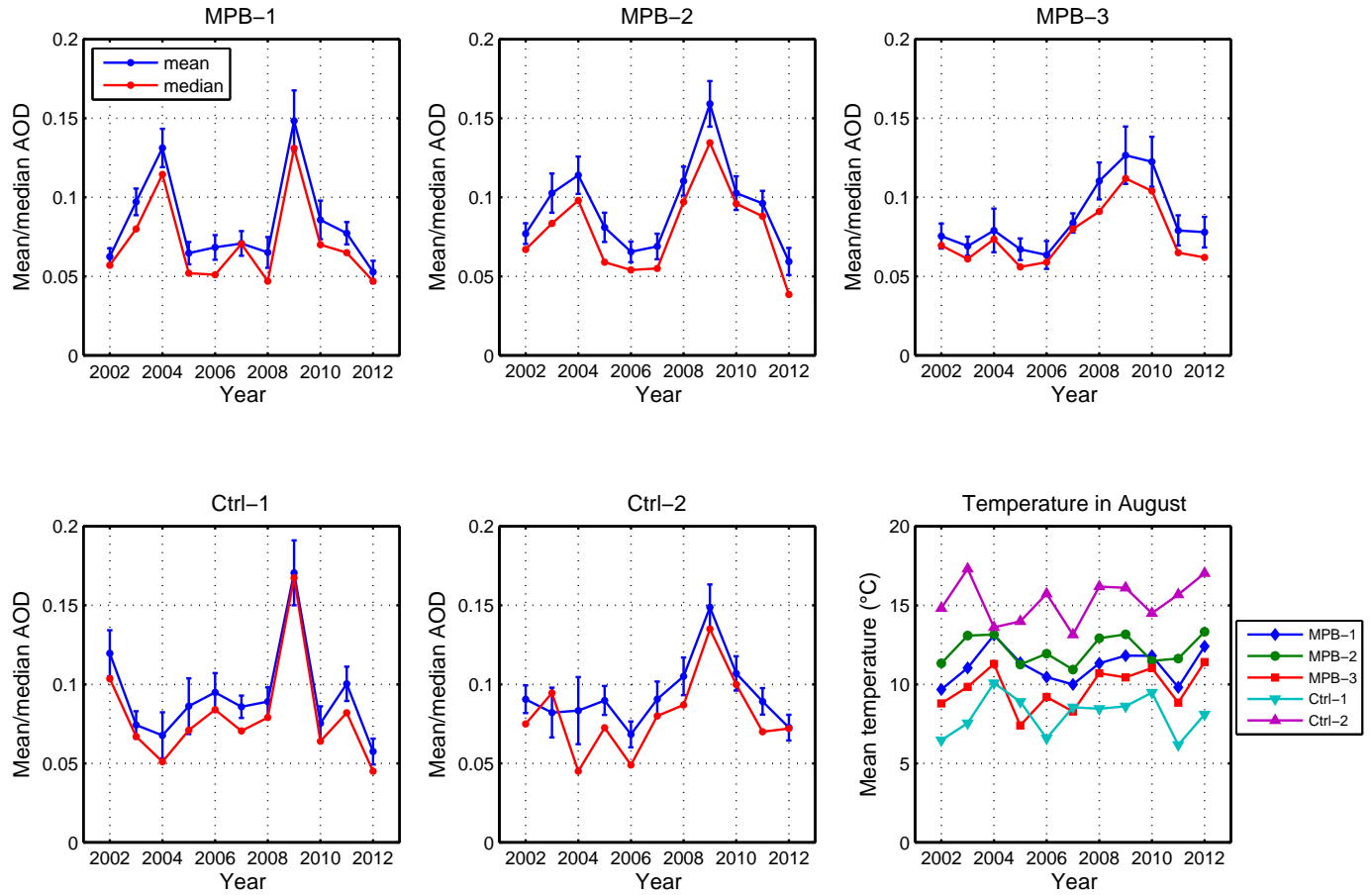

Figure 7. Mean ( $\pm 95 \%$ confidence interval) and median aerosol optical depth (AOD) in August over different areas in western Canada. AOD was analysed from MODIS satellite data in three mountain pine beetle (MPB) outbreak areas (named MPB-1/2/3) and two control (Ctrl-1/2) areas (see Table 2). Effect of daily temperature was taken into account in AOD values. The last panel shows mean temperature in August in the analysed areas. Analysed areas are shown on maps in Fig. S1 and on the web page http://goo.gl/maps/m41O5.

$20 \%$ for an area of $3.8 \times 10^{6} \mathrm{~km}^{2}$ (Fig. $6 \mathrm{c}$ ), i.e. $\sim 1.5$ times the insect-infested area, while the largest local increases were over $45 \%$. The influence of increased VOC emissions were also clearly observed hundreds of kilometres downwind of damaged areas, e.g. over the Arctic Ocean with low background $\mathrm{CCN}$ concentrations. Overall, predicted changes in $\mathrm{CCN}$ were relatively low because a large fraction of VOC oxidation products condense onto pre-existing aerosols which can already act as $\mathrm{CCN}$ in unperturbed conditions. Thus enhanced VOC emissions only affect CCN concentrations if the gas-phase emissions can lead to growth of small nucleation and Aitken mode particles up to $\mathrm{CCN}$ size. Taken the increase in aerosol mass and $\mathrm{CCN}$ concentration together, global model simulations suggest that large-scale insect herbivory in the boreal region can affect both direct and indirect aerosol forcing on a regional scale.

\subsection{Satellite observations}

Changes in AOD in western Canada were analysed from the MODIS instrument satellite data for an 11-year (20022012) period covering three insect outbreak (MPB-1/2/3) and two control (Ctrl-1/2) areas (see Table 2, Fig. S1). The current MPB outbreak in central British Columbia started in the early 1990s and the areas were selected based on the location of the outbreak as it has expanded over the years (Natural Resources Canada, 2015; ca. in 2000, 2004 and 2010 for
MPB-1, MPB-2 and MPB-3 areas respectively). Days with evidence of forest fire aerosols were excluded in the AOD analysis (see Table S1).

Figure 7 shows the mean AOD values in August over analysed areas in 2002-2012. During years 2002-2004, a clear increase in mean AOD values was observed in MPB-1 and MPB-2 areas (from ca. 0.07 to 0.13 ). In contrast, no clear increase in AOD was observed in MPB-3 and control areas that are located $200-300 \mathrm{~km}$ away from the main infested area. Table 7 shows a pairwise comparison of AOD results (ANCOVA) between different areas for a 2-year period of 2003-2004. The statistical analysis confirmed that the mean AOD was significantly higher in areas located near the starting point of the outbreak (MPB-1 and MPB -2) compared with areas located farther away. During that time period, MPB-1 had a high degree of infestation and MPB-2 was partially infested with MPB whereas no infestation was recorded in other analysis areas (Natural Resources Canada, 2015). After 2004, the mean AOD decreased from ca. 0.13 to 0.07 for subsequent years (2005-2007) in MPB-1 and MPB2 areas. The lower AOD values in outbreak areas in later years could be explained by increased tree mortality. Most of the pine trees near the outbreak starting point (MPB-1) were killed by 2006 (Ministry of Forests, 2015) and therefore VOC emissions from trees were likely lower compared with previous years. Typically, the major tree mortality took 
Table 7. Pairwise comparisons of AOD values (mean difference, standard error and $p$ value/significance) between areas in two outbreak periods (2003-2004 and 2008-2010). Significant differences are highlighted in bold text.

\begin{tabular}{rlrrr|rrr}
\hline & & \multicolumn{2}{c}{$2003-2004$} & \multicolumn{2}{c}{$2008-2010$} & \\
Pairs in comparison & Mean difference & Std. error & $p$ value & Mean difference & Std. error & $p$ value \\
\hline MPB-1 & MPB-2 & 0.004 & 0.005 & 0.389 & $-\mathbf{0 . 0 3 6}$ & 0.005 & 0.000 \\
& MPB-3 & $\mathbf{0 . 0 3 9}$ & 0.005 & 0.000 & $-\mathbf{0 . 0 2 2}$ & 0.005 & 0.000 \\
& Ctrl-1 & $\mathbf{0 . 0 3 5}$ & 0.006 & 0.000 & $\mathbf{0 . 0 1 4}$ & 0.006 & 0.017 \\
& Ctrl-2 & $\mathbf{0 . 0 3 0}$ & 0.008 & 0.000 & $\mathbf{- 0 . 0 4 3}$ & 0.006 & 0.000 \\
MPB-2 & MPB-1 & -0.004 & 0.005 & 0.389 & $\mathbf{0 . 0 3 6}$ & 0.005 & 0.000 \\
& MPB-3 & $\mathbf{0 . 0 3 4}$ & 0.006 & 0.000 & $\mathbf{0 . 0 1 4}$ & 0.005 & 0.008 \\
& Ctrl-1 & $\mathbf{0 . 0 3 0}$ & 0.007 & 0.000 & $\mathbf{0 . 0 5 0}$ & 0.006 & 0.000 \\
& Ctrl-2 & $\mathbf{0 . 0 2 6}$ & 0.008 & 0.001 & -0.007 & 0.005 & 0.182 \\
MPB-3 & MPB-1 & $-\mathbf{0 . 0 3 9}$ & 0.005 & 0.000 & $\mathbf{0 . 0 2 2}$ & 0.005 & 0.000 \\
& MPB-2 & $-\mathbf{0 . 0 3 4}$ & 0.006 & 0.000 & $\mathbf{- 0 . 0 1 4}$ & 0.005 & 0.008 \\
& Ctrl-1 & -0.004 & 0.006 & 0.506 & $\mathbf{0 . 0 3 6}$ & 0.006 & 0.000 \\
Ctrl-2 & -0.009 & 0.008 & 0.300 & $\mathbf{- 0 . 0 2 1}$ & 0.006 & 0.000 \\
Ctrl-1 & MPB-1 & $-\mathbf{0 . 0 3 5}$ & 0.006 & 0.000 & $\mathbf{- 0 . 0 1 4}$ & 0.006 & 0.017 \\
& MPB-2 & $-\mathbf{0 . 0 3 0}$ & 0.007 & 0.000 & $\mathbf{- 0 . 0 5 0}$ & 0.006 & 0.000 \\
& MPB-3 & 0.004 & 0.006 & 0.506 & $\mathbf{- 0 . 0 3 6}$ & 0.006 & 0.000 \\
Ctrl-2 & Ctrl-2 & -0.004 & 0.009 & 0.634 & $\mathbf{- 0 . 0 5 7}$ & 0.007 & 0.000 \\
& MPB-1 & $\mathbf{- 0 . 0 3 0}$ & 0.008 & 0.000 & $\mathbf{0 . 0 4 3}$ & 0.006 & 0.000 \\
& MPB-2 & $-\mathbf{0 . 0 2 6}$ & 0.008 & 0.001 & 0.007 & 0.005 & 0.182 \\
& MPB-3 & 0.009 & 0.008 & 0.300 & $\mathbf{0 . 0 2 1}$ & 0.006 & 0.000 \\
& Ctrl-1 & 0.004 & 0.009 & 0.634 & $\mathbf{0 . 0 5 7}$ & 0.007 & 0.000 \\
\hline
\end{tabular}

place approximately 1 decade after the initial outbreak (Ministry of Forests, 2015).

From 2006 to 2011, the leading edge of MPB outbreak moved north and east, approaching the MPB-3 area, and the southern part of the MPB-3 area was infested with MPB by 2010. In MPB-3, a mean AOD in August was increased from ca. 0.06 to 0.12 from 2006 to 2010 ; however, unlike the results from 2002 to 2006, a clear increase in AOD was also observed in control areas (Ctrl-1 and Ctrl-2) that are located $100-200 \mathrm{~km}$ outside of the infested areas (the leading edge of outbreak). In addition, the pairwise comparison for 3-year period of 2008-2010 (Table 7) does not show significant increase in AOD values in the infected areas compared with other areas; in fact the results varied area by area.

The difference between two analysed periods (2002-2004 and 2008-2011) could be explained by the change in total outbreak area - the extremely large herbivore-affected area was reached in 2009 (Meddens et al., 2012; Kurz et al., 2008a), indicating that a large amount of reactive VOCs was emitted from trees to the atmosphere in that region of Canada. VOCs emitted from stressed trees, as well as the SOAs formed from them can be transported by wind over several hundreds of kilometres as shown by our GLOMAP analysis (see Fig. 6) and, therefore, increases in AOD could be observed in an area wider than the original MPB outbreak area.

An alternate explanation also becomes apparent when honing in on the AOD results from 2009. In MPB-1 and Ctrl-1 areas, the AOD values had a clear peak in 2009 com- pared with previous and subsequent years, i.e. around 0.15 while the baseline level is below 0.1. However, the ANCOVA results for 3-year period of 2008-2010 (Table 7) show that at the outbreak starting point (MPB-1), where there was high tree mortality and the main infestation had passed, the mean AOD (3-year average) was significantly lower than in other more active outbreak areas (MPB-2 and MPB-3). This indicates that there might be exceptional reasons for high AOD values in August 2009 when compared with the previous and following years, e.g. weather conditions or forest fires. Based on information from the BC Wildfire Management Branch (2015b), numbers of total fires were significantly higher in 2009 than current 10-year average (3064 vs. 1908). They also stated that "Fire season 2009 will go down in history as one of the busiest due to exceptional weather and fire behaviour conditions" (BC Wildfire Management Branch, 2015a). Despite our best attempts to exclude fire days from the analysis, it is possible that this extreme fire season in 2009 could have some effect on the calculated mean AOD values. For instance, frequent and intense forest fires can raise AOD base levels even in "smoke-free" cases. Furthermore, we had to exclude totally 15 days of 31 from analysis in August 2009, mainly at the beginning of the month (see Table S1), which might affect results.

Clear differences in AOD values between different analysed areas were only detected in August, not in data for the other months or in the data combined for the whole year. This is consistent with the bark beetle attack periods, which 
typically peak in August (Cudmore et al., 2010; Rankin and Borden, 1991).

Mean temperature in August at analysed areas is shown in the last panel Fig. 7. Temperature was found to have a statistically significant effect on the AOD and thus the daily maximum temperature was used as a predictor variable in the ANCOVA model. The model without the temperature effect is not shown in this paper. When the temperature was taken into account in the model, the differences between the outbreak and control areas were enhanced rather than reduced. Maximum temperature was seen to have a reducing effect on AOD within the study period. This is a sign of strong nonlinearity in the effect of temperature to aerosol loading as Goldstein et al. (2009) suggested that the overall effect of temperature is positive in AOD within range from -12 to $+27^{\circ} \mathrm{C}$. However, within the narrow temperature range of this study, Goldstein et al. (2009) show big variation in the aerosol loading and the sign of the temperature effect cannot be specified.

The satellite observations presented here do not provide direct evidence that bark beetle outbreaks increased AOD in outbreak areas, but they agree well with the results of the GLOMAP model simulations presented previously: increased VOC emission caused by biotic stress increased SOA concentration over MPB outbreak areas. Recent simulations on the impact of MPB infestations on terpene emissions and SOA formation in western North America also showed an enhancement peak on SOA concentrations in central British Columbia in 2004 (Berg et al., 2013), which coincides with one of the major AOD peaks presented in Fig. 7. Other sources of increased AOD, including interacting effects between herbivore outbreaks and forest fires, cannot be completely ruled out with this analysis. For example, increased AOD would be observed with increasing frequency of forest fires in insect affected forests dominated by dead or dying trees. To better isolate the effect of herbivore outbreak on VOC emissions and SOA formation in forest regions, more extensive measurement campaigns need to be conducted directly in the field environment.

\section{Conclusions}

Our results suggest that more frequent insect outbreaks in a warming climate, in addition to temperature-dependent increases of VOC emissions, could result in substantial increases in biogenic SOA formation in the boreal zone. The field and laboratory experiments showed a significant increase in VOC emissions and SOA formation after insect feeding. Furthermore, global-scale modelling results and satellite observations indicated a clear increase in CCN concentrations and in AOD values near insect outbreak areas, which affect both aerosol direct and indirect forcing of climate at regional scales. However, the long-term effects of insect outbreaks (e.g. mortality of trees; Långström et al.,
2001, VOC emissions from xylem of dead trees; Hyttinen et al., 2010; Kivimäenpää et al., 2012; Haapanala et al., 2012), and the effects of different tree species (Hyttinen et al., 2010; Eisenbies et al., 2007) needs to be addressed in detail in the future. For instance, conifer trees with a large monoterpene storage capacity in resin ducts can emit reactive VOCs for long periods after intensive herbivore damage whereas the capacity of deciduous trees is very limited.

In the future, anthropogenic emissions (e.g. particulate matter and $\mathrm{SO}_{2}$ ) are expected to be reduced through legislation and introduction of new cleaning technologies; therefore formation of biogenic SOAs will play an even more important role in global climate change (Andreae et al., 2005; Arneth et al., 2009). Additional SOA formation through oxidation of VOCs released from insect stressed trees may also bolster the important sun-screening biosphere-atmosphere feedback system (Ehn et al., 2014; Lovelock, 2003). SOAs could mitigate the impact of global warming on northern terrestrial ecosystems by affecting the Earth's radiation budget but also increase diffuse radiation, which was previously shown to promote plant growth and increase the $\mathrm{CO}_{2}$ sink in vegetation (Mercado et al., 2009). Furthermore, higher concentrations of biotic SOA particles might have adverse effects on human health (Sunil et al., 2007; Rohr, 2013).

We propose that the effect of insect outbreaks on VOC emissions and SOA formation should be considered in future climate predictions.

\section{The Supplement related to this article is available online at doi:10.5194/acp-15-12139-2015-supplement.}

Acknowledgements. We gratefully acknowledge the support of the Academy of Finland (decision no. 110763, 111543, 131019, 131156, 218115, 250348, 252908 and Centre of Excellence Programme 272041), the strategic funding of the University of Eastern Finland (CABI) and the Kone foundation.

Edited by: A. Kiendler-Scharr

\section{References}

Amin, H., Atkins, P. T., Russo, R. S., Brown, A. W., Sive, B., Hallar, A. G., and Huff Hartz, K. E.: Effect of Bark Beetle Infestation on Secondary Organic Aerosol Precursor Emissions, Environ. Sci. Technol., 46, 5696-5703, doi:10.1021/es204205m, 2012.

Andreae, M. O., Jones, C. D., and Cox, P. M.: Strong present-day aerosol cooling implies a hot future, Nature, 435, 1187-1190, 2005.

Arneth, A., Unger, N., Kulmala, M., and Andreae, M. O.: Clean the Air, Heat the Planet?, Science, 326, 672-673, doi:10.1126/science.1181568, 2009. 
Bala, G., Caldeira, K., Wickett, M., Phillips, T. J., Lobell, D. B., Delire, C., and Mirin, A.: Combined climate and carbon-cycle effects of large-scale deforestation, P. Natl. Acad. Sci. USA, 104, 6550-6555, 2007.

BC Wildfire Management Branch: Summary of Previous Fire Seasons (2009): http://bcwildfire.ca/history/summaryarchive.htm\# 2009, last access: 30 October 2015a.

BC Wildfire Management Branch: Fire Averages: http://bcwildfire. ca/History/average.htm, last access: 9 March 2015b.

Berg, A. R., Heald, C. L., Huff Hartz, K. E., Hallar, A. G., Meddens, A. J. H., Hicke, J. A., Lamarque, J.-F., and Tilmes, S.: The impact of bark beetle infestations on monoterpene emissions and secondary organic aerosol formation in western North America, Atmos. Chem. Phys., 13, 3149-3161, doi:10.5194/acp-13-31492013, 2013.

Bergström, R., Hallquist, M., Simpson, D., Wildt, J., and Mentel, T. F.: Biotic stress: a significant contributor to organic aerosol in Europe?, Atmos. Chem. Phys., 14, 13643-13660, doi:10.5194/acp14-13643-2014, 2014.

Berryman, A. A.: The theory and classification of outbreaks, in: Insect outbreaks, edited by: Barbosa, P. and Schultz, J., Academic Press Inc., London, 3-30, 1987.

Blande, J. D., Tiiva, P., Oksanen, E., and Holopainen, J. K.: Emission of herbivore-induced volatile terpenoids from two hybrid aspen (Populus tremula $x$ tremuloides) clones under ambient and elevated ozone concentrations in the field, Glob. Change. Biol., 13, 2538-2550, 2007.

Blande, J. D., Turunen, K., and Holopainen, J. K.: Pine weevil feeding on Norway spruce bark has a stronger impact on needle VOC emissions than enhanced ultraviolet-B radiation, Environ. Pollut., 157, 174-180, 2009.

Bonn, B. and Moortgat, G. K.: Sesquiterpene ozonolysis: Origin of atmospheric new particle formation from biogenic hydrocarbons, Geophys. Res. Lett., 30, 1585, doi:10.1029/2003GL017000, 2003.

Claeys, M., Graham, B., Vas, G., Wang, W., Vermeylen, R., Pashynska, V., Cafmeyer, J., Guyon, P., Andreae, M. O., Artaxo, P., and Maenhaut, W.: Formation of secondary organic aerosols through photooxidation of isoprene, Science, 303, 1173-1176, 2004.

Cudmore, T. J., Björklund, N., Carroll, A. L., and Lindgren, B. S.: Climate change and range expansion of an aggressive bark beetle: evidence of higher beetle reproduction in naive host tree populations, J. Appl. Ecol., 47, 1036-1043, doi:10.1111/j.13652664.2010.01848.x, 2010.

D’Andrea, S. D., Acosta Navarro, J. C., Farina, S. C., Scott, C. E., Rap, A., Farmer, D. K., Spracklen, D. V., Riipinen, I., and Pierce, J. R.: Aerosol size distribution and radiative forcing response to anthropogenically driven historical changes in biogenic secondary organic aerosol formation, Atmos. Chem. Phys., 15, 2247-2268, doi:10.5194/acp-15-2247-2015, 2015.

De Somviele, B., Lyytikäinen-Saarenmaa, P., and Niemelä, P.: Stand edge effects on distribution and condition of Diprionid sawflies, Agric. For. Entomol., 9, 17-30, doi:10.1111/j.14619563.2006.00313.x, 2007.

Ehn, M., Thornton, J. A., Kleist, E., Sipila, M., Junninen, H., Pullinen, I., Springer, M., Rubach, F., Tillmann, R., Lee, B., LopezHilfiker, F., Andres, S., Acir, I.-H., Rissanen, M., Jokinen, T., Schobesberger, S., Kangasluoma, J., Kontkanen, J., Nieminen, T., Kurten, T., Nielsen, L. B., Jorgensen, S., Kjaergaard, H. G.,
Canagaratna, M., Maso, M. D., Berndt, T., Petaja, T., Wahner, A., Kerminen, V.-M., Kulmala, M., Worsnop, D. R., Wildt, J., and Mentel, T. F.: A large source of low-volatility secondary organic aerosol, Nature, 506, 476-479, doi:10.1038/nature13032, 2014.

Eisenbies, M. H., Davidson, C., Johnson, J., Amateis, R., and Gottschalk, K.: Tree mortality in mixed pine-hardwood stands defoliated by the European gypsy moth (Lymantria dispar L.), Forest Science, 53, 683-691, 2007.

Faubert, P., Tiiva, P., Rinnan, Å., Räty, S., Holopainen, J. K., Holopainen, T., and Rinnan, R.: Effect of vegetation removal and water table drawdown on the nonmethane biogenic volatile organic compound emissions in boreal peatland microcosms, Atmos. Environ., 44, 4432-4439, doi:10.1016/j.atmosenv.2010.07.039, 2010.

Fischer, R., Waldner, P., Carnicer, J., Coll, M., Dobbertin, M., Ferretti, M., Hansen, K., Kindermann, G., Lasch-Born, P., Lorenz, M., Marchetto, A., Meining, S., Nieminen, T., Peñuelas, J., Rautio, P., Reyer, C., Roskams, P., and Sánchez, G.: The Condition of Forests in Europe, 2012 Executive Report, ICP Forests, Hamburg, 24 pp., available at: http://www.icp-forests. org/RepEx.htm (last access: 30 October 2015), 2012.

Ghimire, R. P., Markkanen, J. M., Kivimäenpää, M., LyytikäinenSaarenmaa, P., and Holopainen, J. K.: Needle Removal by Pine Sawfly Larvae Increases Branch-Level VOC Emissions and Reduces Below-Ground Emissions of Scots Pine, Environ. Sci. Technol., 47, 4325-4332, doi:10.1021/es4006064, 2013.

Goldstein, A. H., Koven, C. D., Heald, C. L., and Fung, I. Y.: Biogenic carbon and anthropogenic pollutants combine to form a cooling haze over the southeastern United States, P. Natl. Acad. Sci. USA, 106, 8835-8840, doi:10.1073/pnas.0904128106, 2009.

Guenther, A., Hewitt, C. N., Erickson, D., Fall, R., Geron, C., Graedel, T., Harley, P., Klinger, L., Lerdau, M., McKay, W. A., Pierce, T., Scholes, B., Steinbrecher, R., Tallamraju, R., Taylor, J., and Zimmerman, P.: A global model of natural volatile organic compound emissions, J. Geophys. Res.-Atmos., 100, 8873-8892, 1995.

Guenther, A. B., Zimmerman, P. R., Harley, P. C., Monson, R. K., and Fall, R.: Isoprene and monoterpene emission rate variability - model evaluations and sensitivity analyses, J. Geophys. Res.Atmos., 98, 12609-12617, 1993.

Haapanala, S., Hakola, H., Hellén, H., Vestenius, M., Levula, J., and Rinne, J.: Is forest management a significant source of monoterpenes into the boreal atmosphere?, Biogeosciences, 9, 12911300, doi:10.5194/bg-9-1291-2012, 2012.

Hallquist, M., Wenger, J. C., Baltensperger, U., Rudich, Y., Simpson, D., Claeys, M., Dommen, J., Donahue, N. M., George, C., Goldstein, A. H., Hamilton, J. F., Herrmann, H., Hoffmann, T., Iinuma, Y., Jang, M., Jenkin, M. E., Jimenez, J. L., Kiendler-Scharr, A., Maenhaut, W., McFiggans, G., Mentel, Th. F., Monod, A., Prévôt, A. S. H., Seinfeld, J. H., Surratt, J. D., Szmigielski, R., and Wildt, J.: The formation, properties and impact of secondary organic aerosol: current and emerging issues, Atmos. Chem. Phys., 9, 5155-5236, doi:10.5194/acp-9-51552009, 2009.

Hamed, A., Joutsensaari, J., Mikkonen, S., Sogacheva, L., Dal Maso, M., Kulmala, M., Cavalli, F., Fuzzi, S., Facchini, M. C., Decesari, S., Mircea, M., Lehtinen, K. E. J., and Laaksonen, 
A.: Nucleation and growth of new particles in Po Valley, Italy, Atmos. Chem. Phys., 7, 355-376, doi:10.5194/acp-7-355-2007, 2007.

Hao, L. Q., Yli-Pirilä, P., Tiitta, P., Romakkaniemi, S., Vaattovaara, P., Kajos, M. K., Rinne, J., Heijari, J., Kortelainen, A., Miettinen, P., Kroll, J. H., Holopainen, J. K., Smith, J. N., Joutsensaari, J., Kulmala, M., Worsnop, D. R., and Laaksonen, A.: New particle formation from the oxidation of direct emissions of pine seedlings, Atmos. Chem. Phys., 9, 8121-8137, doi:10.5194/acp9-8121-2009, 2009.

Hao, L. Q., Romakkaniemi, S., Yli-Pirilä, P., Joutsensaari, J., Kortelainen, A., Kroll, J. H., Miettinen, P., Vaattovaara, P., Tiitta, P., Jaatinen, A., Kajos, M. K., Holopainen, J. K., Heijari, J., Rinne, J., Kulmala, M., Worsnop, D. R., Smith, J. N., and Laaksonen, A.: Mass yields of secondary organic aerosols from the oxidation of a-pinene and real plant emissions, Atmos. Chem. Phys., 11, 1367-1378, doi:10.5194/acp-11-1367-2011, 2011.

Heald, C. L., Henze, D. K., Horowitz, L. W., Feddema, J., Lamarque, J. F., Guenther, A., Hess, P. G., Vitt, F., Seinfeld, J. H., Goldstein, A. H., and Fung, I.: Predicted change in global secondary organic aerosol concentrations in response to future climate, emissions, and land use change, J. Geophys. Res.-Atmos., 113, D05211, doi:10.1029/2007jd009092, 2008.

Heijari, J., Blande, J. D., and Holopainen, J. K.: Feeding of large pine weevil on Scots pine stem triggers localised bark and systemic shoot emission of volatile organic compounds, Environ. Exp. Bot., 71, 390-398, doi:10.1016/j.envexpbot.2011.02.008, 2011.

Helmig, D., Ortega, J., Guenther, A., Herrick, J. D., and Geron, C.: Sesquiterpene emissions from loblolly pine and their potential contribution to biogenic aerosol formation in the Southeastern US, Atmos. Environ., 40, 4150-4157, doi:10.1016/j.atmosenv.2006.02.035, 2006.

Holopainen, J. K. and Gershenzon, J.: Multiple stress factors and the emission of plant VOCs, Trends Plant Sci., 15, 176-184, 2010.

Hyttinen, M., Masalin-Weijo, M., Kalliokoski, P., and Pasanen, P.: Comparison of VOC emissions between air-dried and heat-treated Norway spruce (Picea abies), Scots pine (Pinus sylvesteris) and European aspen (Populus tremula) wood, Atmos. Environ., 44, 5028-5033, doi:10.1016/j.atmosenv.2010.07.018, 2010.

IPCC: Climate Change 2013: The Physical Science Basis, Contribution of Working Group I to the Fifth Assessment Report of the Intergovernmental Panel on Climate Change, Cambridge University Press, Cambridge, United Kingdom and New York, NY, USA, 1535 pp., 2013.

Jimenez, J. L., Canagaratna, M. R., Donahue, N. M., Prevot, A. S. H., Zhang, Q., Kroll, J. H., DeCarlo, P. F., Allan, J. D., Coe, H., Ng, N. L., Aiken, A. C., Docherty, K. S., Ulbrich, I. M., Grieshop, A. P., Robinson, A. L., Duplissy, J., Smith, J. D., Wilson, K. R., Lanz, V. A., Hueglin, C., Sun, Y. L., Tian, J., Laaksonen, A., Raatikainen, T., Rautiainen, J., Vaattovaara, P., Ehn, M., Kulmala, M., Tomlinson, J. M., Collins, D. R., Cubison, M. J., Dunlea, E. J., Huffman, J. A., Onasch, T. B., Alfarra, M. R., Williams, P. I., Bower, K., Kondo, Y., Schneider, J., Drewnick, F., Borrmann, S., Weimer, S., Demerjian, K., Salcedo, D., Cottrell, L., Griffin, R., Takami, A., Miyoshi, T., Hatakeyama, S., Shimono, A., Sun, J. Y., Zhang, Y. M., Dzepina, K., Kimmel, J. R., Sueper, D., Jayne, J. T., Herndon, S. C., Trimborn, A.
M., Williams, L. R., Wood, E. C., Middlebrook, A. M., Kolb, C. E., Baltensperger, U., and Worsnop, D. R.: Evolution of Organic Aerosols in the Atmosphere, Science, 326, 1525-1529, doi:10.1126/science.1180353, 2009.

Joutsensaari, J., Loivamäki, M., Vuorinen, T., Miettinen, P., Nerg, A.-M., Holopainen, J. K., and Laaksonen, A.: Nanoparticle formation by ozonolysis of inducible plant volatiles, Atmos. Chem Phys., 5, 1489-1495, doi:10.5194/acp-5-1489-2005, 2005.

Kalnay, E., Kanamitsu, M., Kistler, R., Collins, W., Deaven, D., Gandin, L., Iredell, M., Saha, S., White, G., Woollen, J., Zhu, Y., Leetmaa, A., Reynolds, R., Chelliah, M., Ebisuzaki, W., Higgins, W., Janowiak, J., Mo, K. C., Ropelewski, C., Wang, J., Jenne, R., and Joseph, D.: The NCEP/NCAR 40-Year Reanalysis Project, B. Am. Meteorol. Soc., 77, 437-471, 1996.

Kanakidou, M., Seinfeld, J. H., Pandis, S. N., Barnes, I., Dentener, F. J., Facchini, M. C., Van Dingenen, R., Ervens, B., Nenes, A., Nielsen, C. J., Swietlicki, E., Putaud, J. P., Balkanski, Y., Fuzzi, S., Horth, J., Moortgat, G. K., Winterhalter, R., Myhre, C. E. L., Tsigaridis, K., Vignati, E., Stephanou, E. G., and Wilson, J.: Organic aerosol and global climate modelling: a review, Atmos. Chem. Phys., 5, 1053-1123, doi:10.5194/acp-5-1053-2005, 2005.

Kavouras, I. G., Mihalopoulos, N., and Stephanou, E. G.: Formation of atmospheric particles from organic acids produced by forests, Nature, 395, 683-686, 1998.

Kivimäenpää, M., Magsarjav, N., Ghimire, R., Markkanen, J.M., Heijari, J., Vuorinen, M., and Holopainen, J. K.: Influence of tree provenance on biogenic VOC emissions of Scots pine (Pinus sylvestris) stumps, Atmos. Environ., 60, 477-485, doi::10.1016/j.atmosenv.2012.07.018, 2012.

Kokkola, H., Yli-Pirilä, P., Vesterinen, M., Korhonen, H., Keskinen, H., Romakkaniemi, S., Hao, L., Kortelainen, A., Joutsensaari, J., Worsnop, D. R., Virtanen, A., and Lehtinen, K. E. J.: The role of low volatile organics on secondary organic aerosol formation, Atmos. Chem. Phys., 14, 1689-1700, doi:10.5194/acp-14-16892014, 2014.

Kroll, J. H. and Seinfeld, J. H.: Chemistry of secondary organic aerosol: Formation and evolution of low-volatility organics in the atmosphere, Atmos. Environ., 42, 3593-3624, doi:10.1016/j.atmosenv.2008.01.003, 2008.

Kulmala, M., Kontkanen, J., Junninen, H., Lehtipalo, K., Manninen, H. E., Nieminen, T., Petäjä, T., Sipilä, M., Schobesberger, S., Rantala, P., Franchin, A., Jokinen, T., Järvinen, E., Äijälä, M., Kangasluoma, J., Hakala, J., Aalto, P. P., Paasonen, P., Mikkilä, J., Vanhanen, J., Aalto, J., Hakola, H., Makkonen, U., Ruuskanen, T., Mauldin, R. L., Duplissy, J., Vehkamäki, H., Bäck, J., Kortelainen, A., Riipinen, I., Kurtén, T., Johnston, M. V., Smith, J. N., Ehn, M., Mentel, T. F., Lehtinen, K. E. J., Laaksonen, A., Kerminen, V.-M., and Worsnop, D. R.: Direct Observations of Atmospheric Aerosol Nucleation, Science, 339, 943 946, doi:10.1126/science.1227385, 2013.

Kurz, W. A., Dymond, C. C., Stinson, G., Rampley, G. J., Neilson, E. T., Carroll, A. L., Ebata, T., and Safranyik, L.: Mountain pine beetle and forest carbon feedback to climate change, Nature, 452, 987-990, 2008a.

Kurz, W. A., Stinson, G., Rampley, G. J., Dymond, C. C., and Neilson, E. T.: Risk of natural disturbances makes future contribution of Canada's forests to the global carbon cycle highly uncertain, P. Natl. Acad. Sci. USA, 105, 1551-1555, 2008b. 
Laaksonen, A., Kulmala, M., O’Dowd, C. D., Joutsensaari, J., Vaattovaara, P., Mikkonen, S., Lehtinen, K. E. J., Sogacheva, L., Dal Maso, M., Aalto, P., Petäjä, T., Sogachev, A., Yoon, Y. J., Lihavainen, H., Nilsson, D., Facchini, M. C., Cavalli, F., Fuzzi, S., Hoffmann, T., Arnold, F., Hanke, M., Sellegri, K., Umann, B., Junkermann, W., Coe, H., Allan, J. D., Alfarra, M. R., Worsnop, D. R., Riekkola, M.-L., Hyötyläinen, T., and Viisanen, Y.: The role of VOC oxidation products in continental new particle formation, Atmos. Chem. Phys., 8, 2657-2665, doi:10.5194/acp-82657-2008, 2008.

Lee, A., Goldstein, A. H., Kroll, J. H., Ng, N. L., Varutbangkul, V., Flagan, R. C., and Seinfeld, J. H.: Gas-phase products and secondary aerosol yields from the photooxidation of 16 different terpenes, J. Geophys. Res.-Atmos., 111, D17305, doi:10.1029/2006jd007050, 2006.

Levy, R. C., Remer, L. A., Kleidman, R. G., Mattoo, S., Ichoku, C., Kahn, R., and Eck, T. F.: Global evaluation of the Collection 5 MODIS dark-target aerosol products over land, Atmos. Chem. Phys., 10, 10399-10420, doi:10.5194/acp-10-10399-2010, 2010.

Lovelock, J.: Gaia: The living Earth, Nature, 426, 769-770, 2003.

Långström, B., Annila, E., Hellqvist, C., Varama, M., and Niemelä, P.: Tree mortality, needle biomass recovery and growth losses in Scots pine following defoliation by Diprion pini (L.) and subsequent attack by Tomicus piniperda (L.), Scand. J. Forest Res., 16, 342-353, doi:10.1080/02827580152496731, 2001.

McVay, R. C., Cappa, C. D., and Seinfeld, J. H.: Vapor-Wall Deposition in Chambers: Theoretical Considerations, Environ. Sci. Technol., 48, 10251-10258, doi:10.1021/es502170j, 2014.

Meddens, A. J. H., Hicke, J. A., and Ferguson, C. A.: Spatiotemporal patterns of observed bark beetle-caused tree mortality in British Columbia and the western United States, Ecol. Appl., 22, 1876-1891, doi:10.1890/11-1785.1, 2012.

Mentel, Th. F., Kleist, E., Andres, S., Dal Maso, M., Hohaus, T., Kiendler-Scharr, A., Rudich, Y., Springer, M., Tillmann, R., Uerlings, R., Wahner, A., and Wildt, J.: Secondary aerosol formation from stress-induced biogenic emissions and possible climate feedbacks, Atmos. Chem. Phys., 13, 8755-8770, doi:10.5194/acp-13-8755-2013, 2013.

Mercado, L. M., Bellouin, N., Sitch, S., Boucher, O., Huntingford, C., Wild, M., and Cox, P. M.: Impact of changes in diffuse radiation on the global land carbon sink, Nature, 458, 1014-1017, 2009.

Mikkonen, S., Korhonen, H., Romakkaniemi, S., Smith, J. N., Joutsensaari, J., Lehtinen, K. E. J., Hamed, A., Breider, T. J., Birmili, W., Spindler, G., Plass-Duelmer, C., Facchini, M. C., and Laaksonen, A.: Meteorological and trace gas factors affecting the number concentration of atmospheric Aitken $\left(D_{\mathrm{p}}=50 \mathrm{~nm}\right)$ particles in the continental boundary layer: parameterization using a multivariate mixed effects model, Geosci. Model Dev., 4, 1-13, doi:10.5194/gmd-4-1-2011, 2011.

Mikkonen, S., Laine, M., Mäkelä, H. M., Gregow, H., Tuomenvirta, H., Lahtinen, M., and Laaksonen, A.: Trends in the average temperature in Finland, 1847-2013, Stoch Environ Res Risk Assess, 1-9, doi:10.1007/s00477-014-0992-2, 2014.

Ministry of Forests, Lands and Natural Resource Operations: Provincial-Level Projection of the Current Mountain Pine Beetle Outbreak, available at: http://www.for.gov.bc.ca/hre/bcmpb/, last access: 9 March 2015.
Natural Resources Canada: Mountain pine beetle - The threat of mountain pine beetle to Canada's boreal forest, available at: http: //www.nrcan.gc.ca/forests/insects-diseases/13381, last access: 9 March 2015.

Nenes, A. and Seinfeld, J. H.: Parameterization of cloud droplet formation in global climate models, J. Geophys. Res.-Atmos., 108, 4415, doi:10.1029/2002jd002911, 2003.

Ng, N. L., Kroll, J. H., Keywood, M. D., Bahreini, R., Varutbangkul, V., Flagan, R. C., Seinfeld, J. H., Lee, A., and Goldstein, A. H.: Contribution of first- versus second-generation products to secondary organic aerosols formed in the oxidation of biogenic hydrocarbons, Environ. Sci. Technol., 40, 2283-2297, doi:10.1021/es052269u, 2006.

Niemelä, P., Chapin, F. S., Danell, K., and Bryant, J. P.: Herbivorymediated responses of selected boreal forests to climatic change, Climate Change, 48, 427-440, 2001.

NOAA: NCEP Reanalysis data provided by the NOAA/OAR/ESRL PSD, Boulder, Colorado, USA, available at: http://www.esrl. noaa.gov/psd/, last access: 4 April 2014.

Odum, J. R., Hoffmann, T., Bowman, F., Collins, D., Flagan, R. C., and Seinfeld, J. H.: Gas/particle partitioning and secondary organic aerosol yields, Environ. Sci. Technol., 30, 2580-2585, 1996.

Pankow, J. F.: An absorption-model of gas-particle partitioning of organic-compounds in the atmosphere, Atmos. Environ., 28, 185-188, 1994.

Potapov, P., Hansen, M. C., Stehman, S. V., Loveland, T. R., and Pittman, K.: Combining MODIS and Landsat imagery to estimate and map boreal forest cover loss, Remote Sens. Environ., 112, 3708-3719, 2008.

Rankin, L. J. and Borden, J. H.: Competitive interactions between the mountain pine beetle and the pine engraver in lodgepole pine, Can. J. Forest Res., 21, 1029-1036, doi:10.1139/x91-141, 1991.

Rohr, A. C.: The health significance of gas- and particle-phase terpene oxidation products: A review, Environ. Int., 60, 145-162, doi:10.1016/j.envint.2013.08.002, 2013.

Semiz, G., Heijari, J., Isik, K., and Holopainen, J. K.: Variation in needle terpenoids among Pinus sylvestris L. (Pinaceae) provenances from Turkey, Biochem. Syst. Ecol., 35, 652-661, doi:10.1016/j.bse.2007.05.013, 2007.

Shilling, J. E., Chen, Q., King, S. M., Rosenoern, T., Kroll, J. H., Worsnop, D. R., McKinney, K. A., and Martin, S. T.: Particle mass yield in secondary organic aerosol formed by the dark ozonolysis of $\alpha$-pinene, Atmos. Chem. Phys., 8, 2073-2088, doi:10.5194/acp-8-2073-2008, 2008.

Sihto, S.-L., Kulmala, M., Kerminen, V.-M., Dal Maso, M., Petäjä, T., Riipinen, I., Korhonen, H., Arnold, F., Janson, R., Boy, M., Laaksonen, A., and Lehtinen, K. E. J.: Atmospheric sulphuric acid and aerosol formation: implications from atmospheric measurements for nucleation and early growth mechanisms, Atmos. Chem. Phys., 6, 4079-4091, doi:10.5194/acp-6-4079-2006, 2006.

Sitch, S., Cox, P. M., Collins, W. J., and Huntingford, C.: Indirect radiative forcing of climate change through ozone effects on the land-carbon sink, Nature, 448, 791-794, 2007.

Song, C., Na, K., and Cocker, D. R.: Impact of the Hydrocarbon to NOx Ratio on Secondary Organic Aerosol Formation, Environ. Sci. Technol., 39, 3143-3149, doi:10.1021/es0493244, 2005. 
Spracklen, D. V., Pringle, K. J., Carslaw, K. S., Chipperfield, M. P., and Mann, G. W.: A global off-line model of sizeresolved aerosol microphysics: I. Model development and prediction of aerosol properties, Atmos. Chem. Phys., 5, $2227-$ 2252, doi:10.5194/acp-5-2227-2005, 2005.

Spracklen, D. V., Carslaw, K. S., Kulmala, M., Kerminen, V.-M., Mann, G. W., and Sihto, S.-L.: The contribution of boundary layer nucleation events to total particle concentrations on regional and global scales, Atmos. Chem. Phys., 6, 5631-5648, doi:10.5194/acp-6-5631-2006, 2006.

Spracklen, D. V., Bonn, B., and Carslaw, K. S.: Boreal forests, aerosols and the impacts on clouds and climate, Philos. T. R. Soc. A, 366, 4613-4626, doi:10.1098/rsta.2008.0201, 2008a.

Spracklen, D. V., Carslaw, K. S., Kulmala, M., Kerminen, V. M., Sihto, S. L., Riipinen, I., Merikanto, J., Mann, G. W., Chipperfield, M. P., Wiedensohler, A., Birmili, W., and Lihavainen, H.: Contribution of particle formation to global cloud condensation nuclei concentrations, Geophys. Res. Lett., 35, L06808, doi:10.1029/2007gl033038, 2008b.

Statistics Canada: Population and dwelling counts, for Canada, provinces and territories, and census subdivisions (municipalities), 2011 and 2006 censuses, available at: http://www12. statcan.gc.ca/, last access: 9 March 2015.

Sunil, V. R., Laumbach, R. J., Patel, K. J., Turpin, B. J., Lim, H.-J., Kipen, H. M., Laskin, J. D., and Laskin, D. L.: Pulmonary effects of inhaled limonene ozone reaction products in elderly rats, Toxicol. Appl. Pharm., 222, 211-220, doi:10.1016/j.taap.2007.05.003, 2007.
Tsigaridis, K. and Kanakidou, M.: Secondary organic aerosol importance in the future atmosphere, Atmos. Environ., 41, 46824692, doi:10.1016/j.atmosenv.2007.03.045, 2007.

Tunved, P., Hansson, H. C., Kerminen, V. M., Strom, J., Dal Maso, M., Lihavainen, H., Viisanen, Y., Aalto, P. P., Komppula, M., and Kulmala, M.: High natural aerosol loading over boreal forests, Science, 312, 261-263, 2006a.

Tunved, P., Korhonen, H., Strom, J., Hansson, H. C., Lehtinen, K. E. J., and Kulmala, M.: Is nucleation capable of explaining observed aerosol integral number increase during southerly transport over Scandinavia?, Tellus B, 58, 129-140, doi:10.1111/j.16000889.2006.00176.x, 2006b.

Veteli, T. O., Lahtinen, A., Repo, T., Niemelä, P., and Varama, M.: Geographic variation in winter freezing susceptibility in the eggs of the European pine sawfly (Neodiprion sertifer), Agric. For. Entomol., 7, 115-120, 2005.

Went, F. W.: Blue Hazes in the Atmosphere, Nature, 187, 641-643, 1960.

Zhang, X., Cappa, C. D., Jathar, S. H., McVay, R. C., Ensberg, J. J., Kleeman, M. J., and Seinfeld, J. H.: Influence of vapor wall loss in laboratory chambers on yields of secondary organic aerosol, P. Natl. Acad. Sci. USA, 111, 5802-5807, doi:10.1073/pnas.1404727111, 2014. 